\title{
CAR T-Cells in Multiple Myeloma: State of the Art and Future Directions
}

\begin{abstract}
Luis Gerardo Rodríguez-Lobato ${ }^{1,2 t \neq}$, Maya Ganzetti ${ }^{1,3 t \neq}$, Carlos Fernández de Larrea ${ }^{2 \ddagger}$, Michael Hudecek ${ }^{1 \neq}$, Hermann Einsele ${ }^{1 \neq}$ and Sophia Danhof ${ }^{1 * \neq}$

${ }^{1}$ Division of Medicine II, University Hospital Würzburg, Würzburg, Germany, ${ }^{2}$ Amyloidosis and Multiple Myeloma Unit, Department of Hematology, Hospital Clínic of Barcelona, Institut d'Investigacions Biomèdiques August Pi i Sunyer (IDIBAPS), Barcelona, Spain, ${ }^{3}$ Unit of Hematology and Bone Marrow Transplantation, IRCCS San Raffaele Scientific Institute, Milan, Italy
\end{abstract}

Despite recent therapeutic advances, the prognosis of multiple myeloma (MM) patients remains poor. Thus, new strategies to improve outcomes are imperative. Chimeric antigen receptor (CAR) T-cell therapy has changed the treatment landscape of B-cell malignancies, providing a potentially curative option for patients who are refractory to standard treatment. Long-term remissions achieved in patients with acute lymphoblastic leukemia and Non-Hodgkin Lymphoma encouraged its further development in MM. B-cell maturation antigen (BCMA)-targeted CAR T-cells have established outstanding results in heavily pre-treated patients. However, several other antigens such as SLAMF7 and CD44v6 are currently under investigation with promising results. Idecabtagene vicleucel is expected to be approved soon for clinical use. Unfortunately, relapses after CAR T-cell infusion have been reported. Hence, understanding the underlying mechanisms of resistance is essential to promote prevention strategies and to enhance CAR T-cell efficacy. In this review we provide an update of the most recent clinical and pre-clinical data and we elucidate both, the potential and the challenges of CAR T-cell therapy in the future.

Keywords: multiple myeloma, immunotherapy, chimeric antigen receptor, B-cell maturation antigen, T-cell, cytokine release syndrome

\section{INTRODUCTION}

Multiple myeloma (MM), an incurable malignancy in most of the cases, is characterized by an uncontrolled proliferation of clonal plasma-cells in the bone marrow that produces aberrant quantity of monoclonal immunoglobulins (Ig) and end-organ damage (hypercalcemia, renal insufficiency, anemia, and/or bone lytic lesions). MM is the second most commonly diagnosed hematologic malignancy accounting for $\sim 1 \%$ of all cancer types with an incidence rate of $6-7$ cases per 100,000 persons per year (1).

The spectrum of treatment modalities of this disease has expanded significantly, with the introduction of novel agents including proteasome inhibitors (PI), immunomodulatory drugs (IMiD), and monoclonal antibodies (mAb). Despite these considerable advances, most MM patients eventually relapse and become resistant to treatment (1). In this regard, novel immunotherapeutic approaches have been developed to harness the intrinsic immune system against malignant cells.

Chimeric antigen receptor (CAR) T-cell therapy has emerged as potent treatment strategy against B-cell neoplasms with impressive outcomes and manageable toxicity (2-4). In the late 80's and early 90's, two international groups started working on CAR $(5,6)$. Kuwana et al. constructed 
a chimeric receptor molecule joining the Ig-derived variable regions and T-cell receptor-derived constant regions (5). Eshhar et al. (6) designed the CAR as a tool to equip T-cells with potent and specific anti-tumor efficacy and to overcome the limitations of the MHC-restricted T-cell activation in cellular cancer therapy, because reduction or loss of MHC class I molecules is frequently observed during malignant transformation. In the last 2 decades, efforts in the field focused on improving CAR design in order to promote efficacy and in vivo persistence of CAR T-cells. Firstgeneration CARs have been replaced by more potent secondand third-generation CARs. Since 2003, CD19-targeted secondgeneration CARs have been developed and subsequently tested in B-cell malignancies. The FDA approvals of two CD19 CAR T-cell products in 2017 were based on results obtained from two pivotal studies showing remarkable results in patients with acute lymphoblastic leukemia and certain types of large Bcell lymphomas $(2,4)$. In MM, CAR-T cell therapy is still in its infancy. First clinical studies investigated CAR T-cells directed against Lewis Y antigen (7), CD19 (8), CD138 (9), and free light chain (10) in patients with relapsed/refractory (RR) MM. However, most promising results have been reported for BCMA-targeted CAR T-cells. Tremendous enthusiasm has fueled considerable efforts to define the optimal target antigen for CAR T-cell therapy in MM. Here, we discuss the latest outcomes of the most important clinical trials and provide an overview of different strategies to overcome resistance mechanisms against CAR T-cell therapy in MM.

\section{CAR CONSTRUCT}

A CAR is a recombinant receptor to re-direct $\mathrm{T}$ cells against selected antigens on the surface of tumor cells. It consists of different components (Figure 1). The extracellular binding moiety is usually derived from the heavy $(\mathrm{VH})$ and light chain variable domains $(\mathrm{LH})$ of a $\mathrm{mAb}$ that are linked in the form of single chain variable fragment $(\mathrm{scFv})$. The hinge or spacer is designed with Ig-like domains, and the transmembrane domain from CD $8 \alpha$. The intracellular moiety contains the CD3 $\zeta$ signaling chain of the $\mathrm{T}$-cell receptor and provides the first signal for $\mathrm{T}$ cell activation. Second and third generation CARs have one and two costimulatory domains, respectively (e.g., CD28, 4-1BB, or OX40) to promote CAR T-cell survival and proliferation. Fourth generation CAR T-cells, also known as armored CAR T-cells, produce cytokines that enhance CAR T-cell function or modify the tumor microenvironment (11).

\section{TARGET ANTIGENS}

The identification of suitable tumor-associated target antigens is essential for successful CAR T-cell therapy. In general, three prerequisites are required to enable both, effectiveness and safety. First, the antigen must be expressed on the tumor cell surface. Indeed, CAR binding occurs in an MHC-independent fashion (5) reducing the risk of immune escape due to HLA downregulation (12). However, expanding the pool of targetable antigens might

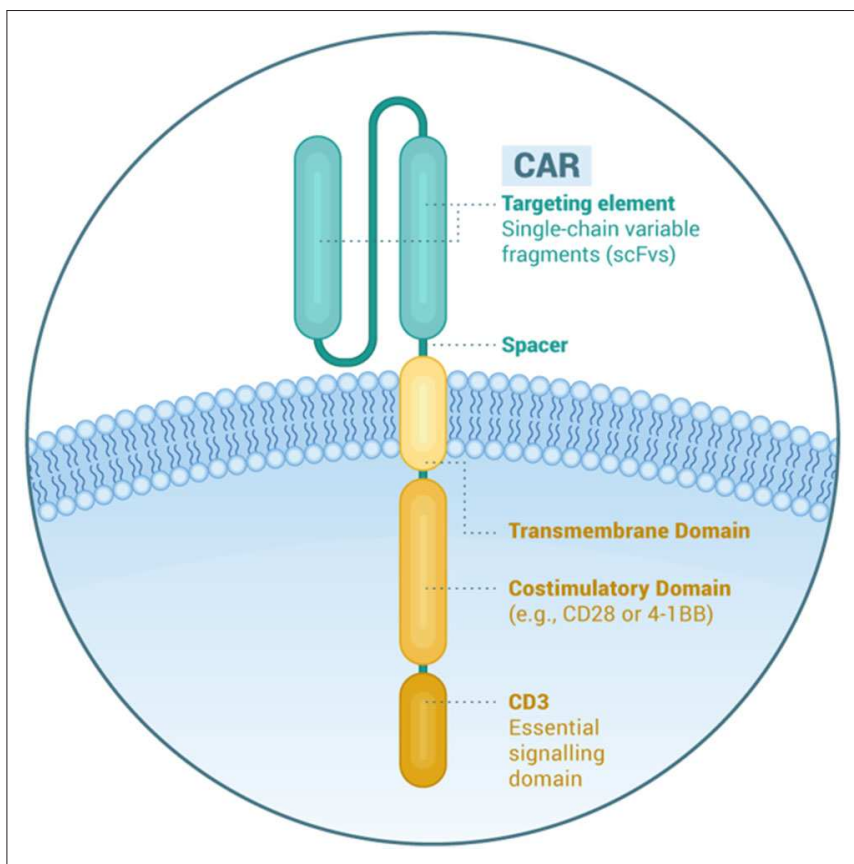

FIGURE 1 | Structural elements of a chimeric antigen receptor.

allow the treatment of a wider spectrum of tumors, so TCRmimetic CARs recognizing the tumor-antigen/HLA complex have been recently developed (13). Second, the antigen must be homogeneously expressed on the malignant cells and should ideally be essential for tumor survival (2). Finally, the target must be virtually absent from relevant healthy tissues to minimize on-target, off-tumor effects. Although no CAR T-cell therapy has been approved for the treatment of MM to date, several antigens are under investigation in early-phase clinical trials and preclinical studies (14).

\section{CAR TARGETS IN CLINICAL TRIALS}

\section{B-Cell Maturation Antigen}

B-cell maturation antigen (BCMA; CD269, tumor necrosis factor receptor superfamily member 17/TNFRSF17) is a transmembrane glycoprotein and non-tyrosine kinase receptor. It shares similarities with two other receptors, which are B-cell Activating Factor of the TNF Family receptor (BAFF-R) and transmembrane activator, calcium modulator, and cyclophilin ligand interactor (TACI) (15-17). BCMA is expressed on the surface of late memory B-cells and plasma cells, and the expression is enhanced during B-cell differentiation. It is also expressed on plasmacytoid dendritic cells, but it is neither expressed on non-hemopoietic tissues, nor on hemopoietic stem cells, nor on naïve B-cells $(15,18-22)$. BCMA activation by its ligands, A Proliferation Inducing Ligand (APRIL) and B-cell Activating Factor (BAFF), transmits survival signals, and induces B-cell maturation and differentiation into plasma cells, as well as immunoglobulin (Ig) isotype switching (19, 23-25). In in vivo studies, BCMA knock-out mice display impaired 
survival of long-term plasma cells, but preserved B-cell development, Ig production and early humoral immune response $(19,26)$.

BCMA has been shown to play an important role in the pathogenesis of MM. It is expressed in MM cells and in human myeloma cell lines (27-33) and expression levels are higher on MM cells as compared to normal plasma cells $(32,34,35)$. It is associated with proliferation, survival (by activation of AKT, MAPK, and NF- $\kappa \mathrm{B}$ signaling cascades), and drug resistance by contributing to the immunosuppressive bone marrow microenvironment $(27,35,36)$. Furthermore, it was reported that responses to donor lymphocyte infusions in MM patients after allogeneic stem cell transplantation were associated with the production of anti-BCMA antibodies, highlighting its role as immunotherapy target (37).

BCMA protein can be cleaved by gamma-secretase with subsequent release of soluble BCMA (sBCMA) (38). It is possible that $\mathrm{sBCMA}$ may also play a role in the pathogenesis of MM by sequestering circulating BAFF, thus preventing the stimulation of normal B-cells and plasma cells (39). In addition, high levels of sBCMA have been correlated with a worse prognosis in terms of progression-free survival (PFS) and overall survival (OS) and sBCMA was proposed as a novel biomarker to monitor and predict outcomes in MM (40-42).

The restricted expression of BCMA and its role in the pathogenesis of MM have made BCMA an attractive target for immunotherapies, especially CAR T-cells (21). Nevertheless, the role of the sBCMA remains to be elucidated, since it could interfere with BCMA-targeted immunotherapies (43). Several clinical trials with diverse BCMA-CAR T-cell constructs in patients with RRMM are ongoing, and the currently available data are encouraging. The next sections and Table 1 summarize the most important aspects of selected clinical trials with CAR T-cells targeting BCMA.

\section{NATIONAL CANCER INSTITUTE CAR T-CELL}

The first-in-human phase 1 clinical trial (NCT02215967) using an anti-BCMA CAR T-cell product with a CD28 costimulatory domain was conducted at the National Cancer Institute (NCI) $(21,44,67)$. This phase 1 dose escalation trial analyzed four dose levels: $0.3 \times 10^{6}, 1 \times 10^{6}, 3 \times 10^{6}$, and $9 \times 10^{6} \mathrm{CAR}$ T-cells/kg of bodyweight. Patients received cyclophosphamide (Cy) and fludarabine (Flu) before BCMA CAR T-cell infusion. Twenty-four heavily treated RRMM patients were enrolled, 16 of them received the highest dose level. The lowest doses showed a minimal anti-MM activity with an overall response rate (ORR) of 20\%; however, in the highest dose level the ORR was $81 \%, 63 \%$ of patients achieved a very good partial response (VGPR) or better, and the median event-free survival (EFS) was 31 weeks. Notably, all patients who achieved a partial response $(\mathrm{PR})$ or better were found to be minimal residual disease (MRD)-negative by bone marrow flow cytometry. Better responses were associated with high-peak CAR T-cell levels and with sBCMA decrease. Regarding adverse events (AE), the first two patients treated at the highest dose level developed severe cytokine-release syndrome (CRS), therefore it was decided to limit eligibility to patients with less than $30 \%$ of bone marrow infiltration. Nevertheless, CRS was observed in $94 \%$ of the patients (grade $\geq 3$ in $38 \%$, no CRS-related mortality [CRS$\mathrm{RM}]$ ); while neurotoxicity was limited to confusion or delirium in the setting of severe CRS (grade $\geq 3$ in 19\%) (44,67). This trial represented the first proof-of-concept that BCMA CAR Tcells are effective against RRMM and is the first description of the loss of BCMA from myeloma cells after BCMA CAR T-cell infusion. However, the high incidence of CRS and the subsequent eligibility restriction to patients with low malignant plasma-cell burden underlined the need for further optimization of this cell product.

\section{LCAR-B38M (JNJ-68284528)}

Nanjing Legend Biotech developed a dual epitope-binding CAR containing two llama-derived heavy chain variable fragments against different BCMA epitopes (VHH1 and VHH2) and a 4$1 \mathrm{BB}$ costimulatory domain. The results from the phase 1 clinical trial (LEGEND-2; NCT03090659) have been published in two independent studies and were updated at the last American Society of Hematology (ASH) meeting (45-47). The first study enrolled 57 RRMM patients with a median of 3 prior lines of therapy. All patients received $\mathrm{Cy}$ as conditioning regimen and the CAR T-cell dose was given in 3 split infusions $(20,30$, and $50 \%$ of total dose over 7 days). CRS was seen in $89 \%$ of patients (grade $\geq 3$ in $7 \%$, no CRS-RM) and grade 1 immune effector cell-associated neurotoxicity syndrome (ICANS) was observed in one patient. The median time to response was 1 month. ORR was observed in $88 \%$ of patients (with a CR rate of $74 \%$ and MRD-negative disease in 68\%). A correlation between BCMA expression and clinical response was not reported. After a median follow-up of 19 months, the median PFS was 20 months in all-treated patients, and 28 months in patients achieving MRDnegativity. The 18 -month OS was $68 \%$ with a median duration of response (DOR) of 22 months (45).

The second study analyzed 17 RRMM patients who received LCAR-B38M in one vs. three infusions of the total CAR Tcell dose, after lymphodepleting chemotherapy over 3 days. Regarding toxicity, CRS was reported in all patients, $41.2 \%$ had grade $\geq 3$ and one patient died due to severe CRS and tumor lysis syndrome. Severity of CRS was associated with the amount of BCMA expressed on the clonal plasma cells. There were no differences in terms of response among the two delivery subgroups. The ORR was $88.2 \%$, with $76.5 \%$ stringent CR (sCR), and after a median follow-up of 13.9 months, 1-y PFS and 1-y OS were 52.9 and $82.3 \%$, respectively. The investigators found that patients who had received a previous autologous stem cell transplantation (ASCT) had more durable responses, and that the presence of anti-CAR antibodies constituted a high-risk factor for relapse (47).

As a result of these findings, a phase $1 b / 2$ clinical trial is ongoing in the United States (CARTITUDE-1, NCT 03548207), and a phase 2 confirmatory study has started in China 
TABLE 1 | Selected BCMA CAR T-cell clinical trials in multiple myeloma.

\begin{tabular}{|c|c|c|c|c|c|c|c|c|}
\hline $\begin{array}{l}\text { Clinical } \\
\text { trial/CAR }\end{array}$ & $\begin{array}{l}\text { CAR construct } \\
\text { specifications }\end{array}$ & $N$ & $\begin{array}{l}\text { Prior } \\
\text { lines, } \\
\text { median }\end{array}$ & $\begin{array}{l}\text { Lymphodepletion } \\
\text { protocol }\end{array}$ & CAR T-cell dose & Response & Survival & $\begin{array}{l}\text { CRS (grade } \geq 3 \text { ) } \\
\text { CRS-related } \\
\text { mortality } \\
\text { ICANS (grade } \geq 3 \text { ) }\end{array}$ \\
\hline $\mathrm{NCl}(44)$ & $\begin{array}{l}\gamma \text {-retrovirus } \\
\text { scFv murine } \\
\text { CD28 }\end{array}$ & $\begin{array}{l}24 \\
(16 \mathrm{HD})\end{array}$ & $9.5(\mathrm{HD})$ & $\mathrm{Cy} / \mathrm{Flu}$ & $0.3-9.0 \times 10^{6} / \mathrm{kg}$ & $\begin{array}{l}\text { ORR 81\% ( } \geq \text { CR 13\%) } \\
\text { MRD-neg } 69 \%(H D)\end{array}$ & mEFS 7.2 mo & $\begin{array}{l}\text { CRS 94\% (38\%) } \\
\text { CRS-RM 0\% } \\
\text { ICANS NA (19\%) }\end{array}$ \\
\hline $\begin{array}{l}\text { Nanjing Legend/ } \\
\text { LCAR-B38M (47) }\end{array}$ & $\begin{array}{l}\text { Lentivirus } \\
\text { Bi-epitope VHH } \\
\text { 4-1BB }\end{array}$ & 17 & 4 & Cy / Flu & $0.21-1.52 \times 10^{6} / \mathrm{kg}$ & ORR $88.2 \%$ ( $\geq$ CR $76.5 \%$ ) & $\begin{array}{l}1 \text {-y PFS } 52.9 \% \\
1 \text {-y OS } 82.3 \%\end{array}$ & $\begin{array}{l}\text { CRS } 100 \%(41.2 \%) \\
\text { CRS-RM } 1 \text { patient } \\
\text { ICANS NA }\end{array}$ \\
\hline $\begin{array}{l}\text { CARTITUDE-1/ } \\
\text { JNJ68284528 } \\
\text { (LCAR- } \\
\text { B38M) }(48,49)\end{array}$ & $\begin{array}{l}\text { Lentivirus } \\
\text { Bi-epitope VHH } \\
\text { 4-1BB }\end{array}$ & 29 & 5 & Cy/Flu & $0.75 \times 10^{6} / \mathrm{kg}$ & $\begin{array}{l}\text { ORR 100\% (sCR } 86 \%) \\
\text { MRD-neg 100\% }(n=23)\end{array}$ & 9-m PFS 86\% & $\begin{array}{l}\text { CRS 93\% (7\%) } \\
\text { CRS-RM } 1 \text { patient } \\
\text { ICANS 10\% (3\%) }\end{array}$ \\
\hline $\begin{array}{l}\text { Bluebird bio/ } \\
\text { CRB-401/bb2121/ } \\
\text { idecabtagene } \\
\text { vicleucel (51) }\end{array}$ & $\begin{array}{l}\text { Lentivirus } \\
\text { scFv murine } \\
\text { 4-1BB }\end{array}$ & 33 & $7-8$ & Cy/Flu & $50-800 \times 10^{6}$ & ORR 85\% ( $\geq$ CR 45\%) & mPFS 11.8 mo & $\begin{array}{l}\text { CRS } 76 \%(6 \%) \\
\text { CRS-RM 0\% } \\
\text { ICANS } 42 \%(3 \%)\end{array}$ \\
\hline $\begin{array}{l}\text { KarMMA/bb2121/ } \\
\text { idecabtagene } \\
\text { vicleucel }(52,53)\end{array}$ & $\begin{array}{l}\text { Lentivirus } \\
\text { scFv murine } \\
\text { 4-1BB }\end{array}$ & 128 & 6 & Cy/Flu & $150-450 \times 10^{6}$ & ORR 73\% ( $\geq$ CR 33\%) & $\begin{array}{l}\text { mPFS } 8.8 \text { mo } \\
\text { mOS } 19.4 \text { mo }\end{array}$ & $\begin{array}{l}\text { CRS } 84 \%(5.5 \%) \\
\text { CRS-RM } 1 \text { patient } \\
\text { ICANS 18\% (3\%) }\end{array}$ \\
\hline $\begin{array}{l}\text { Bluebird bio/ } \\
\text { CRB-402 } \\
\text { /bb21217 (54) }\end{array}$ & $\begin{array}{l}\text { Lentivirus } \\
\text { scFv murine } \\
4-1 \mathrm{BB} \\
\text { PI3K-inh }\end{array}$ & 33 & 7 & $\mathrm{Cy} / \mathrm{Flu}$ & $\begin{array}{l}1: 150 \times 10^{6} \\
2: 300 \times 10^{6} \\
3: 450 \times 10^{6}\end{array}$ & $\begin{array}{l}\text { 1: ORR } 83 \%(\geq \text { CR 33\%) } \\
\text { 2: ORR 43\% ( } \geq \text { CR 0\%) } \\
\text { 3: ORR } 57 \%(\geq \text { CR 14\%) }\end{array}$ & NA & $\begin{array}{l}\text { CRS 66\% (6\%) } \\
\text { CRS-RM } 1 \text { patient } \\
\text { ICANS 24\% (8\%) }\end{array}$ \\
\hline $\begin{array}{l}\text { FHCRC } \\
\text { FCARH143 (58) }\end{array}$ & $\begin{array}{l}\text { Lentivirus } \\
\text { scFv human } \\
4-1 B B \\
\text { EGFRt }\end{array}$ & 7 & 8 & Cy/Flu & $\begin{array}{l}1: 50 \times 10^{6} \\
2: 150 \times 10^{6} \\
3: 450 \times 10^{6} \\
4: 800 \times 10^{6}\end{array}$ & ORR $100 \%(\geq$ CR $36 \%)$ & NA & $\begin{array}{l}\text { CRS 91\% (0\%) } \\
\text { CRS-RM 0\% } \\
\text { ICANS 9\% (0\%) }\end{array}$ \\
\hline $\begin{array}{l}\text { Poseida } \\
\text { Therapeutics } \\
\text { P-BCMA-101 } \\
(59,60)\end{array}$ & $\begin{array}{l}\text { Non-viral } \\
\text { PiggyBac } \\
\text { scFv human } \\
\text { 4-1BB }\end{array}$ & 23 & 6 & $\mathrm{Cy} / \mathrm{Flu}$ & $\begin{array}{l}1: 0.75 \times 10^{6} / \mathrm{kg} \\
2: 2 \times 10^{6} / \mathrm{kg} \\
3: 6 \times 10^{6} / \mathrm{kg} \\
4: 10 \times 10^{6} / \mathrm{kg} \\
5: 15 \times 10^{6} / \mathrm{kg}\end{array}$ & $\begin{array}{l}\text { ORR } 43-100 \% \text { at } \\
\text { various doses }\end{array}$ & NA & $\begin{array}{l}\text { CRS 9.5\% (0\%) } \\
\text { CRS-RM 0\% } \\
\text { ICANS } 4.8 \%(4.8 \%)\end{array}$ \\
\hline $\begin{array}{l}\text { BRD015 } \\
\text { Tongji } \\
\text { Hospital (61) }\end{array}$ & $\begin{array}{l}\text { Lentivirus } \\
\text { scFv murine } \\
\text { CD28 }\end{array}$ & 28 & NA & Cy/Flu & $5.2-25 \times 10^{6} / \mathrm{kg}$ & ORR 89\% ( $\geq$ CR 61\%) & $\begin{array}{l}\text { BCMA } \geq 50 \%: \\
9.8 \mathrm{mo} \\
\text { BCMA <50\%: } \\
2.1 \mathrm{mo}\end{array}$ & $\begin{array}{l}\text { CRS NA (14.3\%) } \\
\text { CRS-RM 0\% } \\
\text { ICANS NA (NA) }\end{array}$ \\
\hline $\begin{array}{l}\text { CT053 } \\
\text { Multicenter } \\
\text { China (62) }\end{array}$ & $\begin{array}{l}\text { Lentivirus } \\
\text { scFv human } \\
\text { 4-1BB }\end{array}$ & 24 & 4.5 & Cy/Flu & $1.5 \times 10^{8} / \mathrm{kg}$ & ORR $87.5 \%$ ( $\geq$ CR $79 \%$ ) & mPFS 9.2 mo & $\begin{array}{l}\text { CRS } 62.5 \%(0 \%) \\
\text { CRS-RM 0\% } \\
\text { ICANS } 12.5 \%(4 \%)\end{array}$ \\
\hline
\end{tabular}


TABLE 1 | Continued

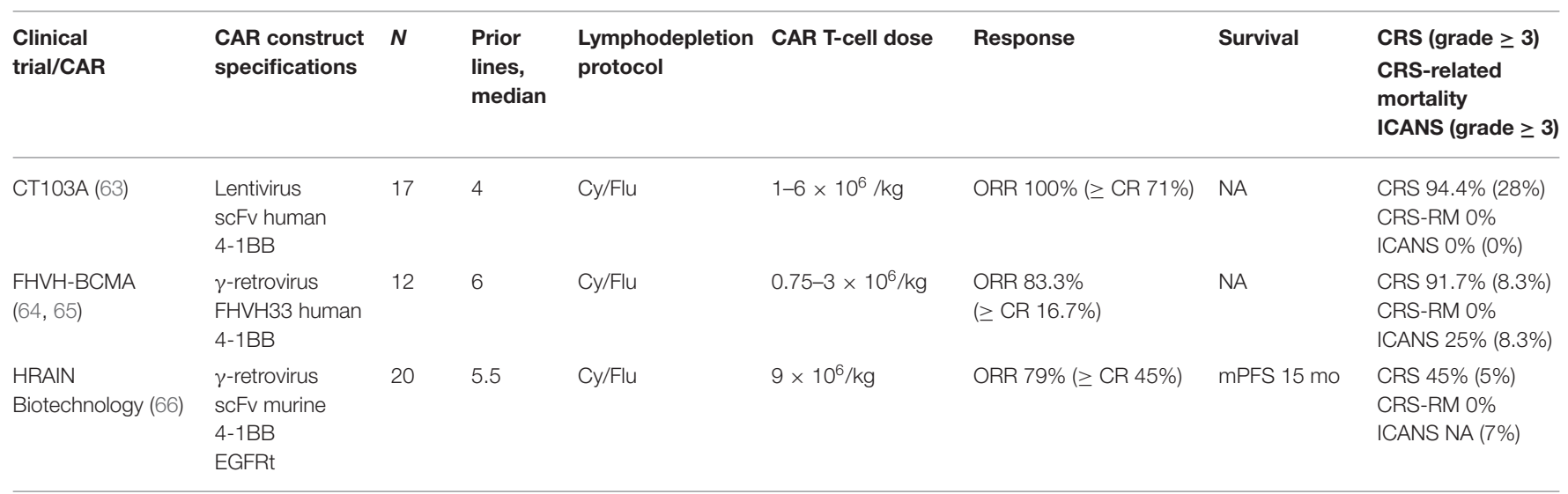

CAR, chimeric antigen receptor; CR, complete response; CRS, cytokine-release syndrome; CRS-RM, CRS related-mortality; Cy, cyclophosphamide; EFS, event-free survival; EGFRt, truncated epidermal growth factor receptor; FHCRC, Fred Hutchinson Cancer Research Center; FHVH33, fully human heavy-chain variable domain; Flu, fludarabine; HD, highest dose; ICANS, immune effector cell-associated neurotoxicity syndrome; m, median, mo, months; MSKCC, Memorial Sloan Kettering Cancer Center; NA, not available; NCl, National Cancer Institute; ORR, overall response rate; OS, overall survival; PFS, progression-free survival; PI3K-inh, phosphoinositide 3-kinase inhibitor; scFv, single-chain variable fragment; UPenn, University of Pennsylvania.

(CARTIFAN-1, NCT03758417). The results of 29 patients who received JNJ68284528 in CARTITUDE-1 trial were presented at the last American Society of Clinical Oncology (ASCO) meeting. Patients were extensively pretreated with 5 prior lines of therapy, $86 \%$ of the them were triple-refractory (PI, IMiDs, and anti-CD38 antibody) and $27 \%$ had high-risk cytogenetic profile. CRS was observed in $93 \%$ of patients with one grade 3 event and one grade 5 event, while ICANS occurred in $10 \%$ of patients (grade $\geq 3$ in $3 \%$ ). The ORR was $100 \%$ with $86 \%$ sCR. Of 16 patients in CR who were evaluable for MRD assessment, 13 were MRD neg at $10^{-5}$ or better and 11 at $10^{-6}$. Baseline BCMA levels were not predictive of response. After a median follow-up of 11.5 months, the 9 -month PFS rate is $86 \%$. The safety and efficacy results are considered largely consistent with LEGEND-2 study $(48,49,68)$. In summary, this cell product has shown impressive results in terms of responses with manageable toxicity; nevertheless, at the moment the follow-up of the patients is short. While this fact obviously limits comparability with other cell products, it might also suggest that the efficacy of CAR T-cells is likely to be increased at earlier stages of the disease.

\section{CART-BCMA}

The University of Pennsylvania developed a BCMA CAR with a fully human scFv and 4-1BB costimulatory molecule (69). This CAR was tested in a phase 1 clinical trial (NCT02546167) which included 25 heavily pretreated RRMM patients. This trial analyzed three sequential cohorts: cohort $1,1 \times 10^{8}$ to $5 \times 10^{8}$ CART-BCMA alone; cohort 2, Cy $1.5 \mathrm{~g} / \mathrm{m}^{2}$ plus $1 \times 10^{7}$ to $5 \times$ $10^{7}$ CART-BCMA cells; cohort 3 , Cy $1.5 \mathrm{~g} / \mathrm{m}^{2}$ plus $1 \times 10^{8}$ to $5 \times 10^{8}$ CART-BCMA cells. CAR T-cells were administered in the outpatient setting as split-dose infusions over 3 days $(10 \%$ on day $0,30 \%$ on day 1 , and $60 \%$ on day 2 ). Inclusion into the trial did not require a prespecified level of BCMA expression on MM cells. CRS was observed in $88 \%$ of the patients with
$32 \%$ grade 3 or 4 , all of whom were treated at the highest dose of CAR T-cells. Neurotoxicity was seen in 32\% and severe neurotoxicity (grade $\geq 3$ in $12 \%$ ) was associated with high tumor burden, high-dose of CAR T-cells and grade 3 or 4 CRS. One patient died after grade 4 CRS complicated by candidemia and disease progression. ORR was $48 \%$ (44\% in cohort $1,20 \%$ in cohort 2, and $64 \%$ in cohort 3 ). The median PFS (mPFS) was 2.1, 1.9, and 4.2 months for cohorts 1, 2, and 3, respectively, and the median OS (mOS) was 11.8 months, 16.3 months, and not reached for cohorts 1, 2, and 3, respectively. Responses were associated with higher premanufacturing $\mathrm{CD} 4^{+} / \mathrm{CD} 8^{+} \mathrm{T}$ cell ratio, and frequency of $\mathrm{CD}_{4} 5 \mathrm{RO}^{-} \mathrm{CD} 27^{+} \mathrm{CD} 8^{+}$T-cells, suggesting that enrichment of less differentiated, more naïve or stem cell memory-like T-cells is important to improve outcomes of this anti-BCMA CAR T-cell product. No correlation was found between baseline BCMA and expansion or response. In patients responding to the treatment, a decrease in BCMA expression was observed that subsequently increased upon progression (50). This trial provided data that lymphodepletion prior to CAR T-cell therapy is no absolute requirement and the optimal regimen is not clear; however, its administration improved clinical outcomes and short-term CAR T-cell expansion suggesting a favorable impact of conditioning therapy.

\section{bb2121 (Idecabtagene Vicleucel)}

This CAR T-cell construct with $4-1 \mathrm{BB}$ as costimulatory molecule was developed by Bluebird bio (70). The multicenter phase 1 study CRB-401 (NCT02658929) consisted of a dose-escalation phase and a dose-expansion phase. The former phase enrolled RRMM patients with $\geq 50 \%$ BCMA expression on plasma cells, while in the latter phase, also patients with less than 50\% BCMA expression could be included. Lymphodepletion with $\mathrm{Cy}$ and Flu was used before a single infusion of bb2121. In the doseescalation phase, 21 patients were enrolled and doses of $50 \times$ 
$10^{6}, 150 \times 10^{6}, 450 \times 10^{6}$, or $800 \times 10^{6}$ CAR T-cells were tested, while in the expansion-phase, 12 patients received 150 $\times 10^{6}$ to $450 \times 10^{6}$ CAR T-cells. Regarding safety, $76 \%$ of patients developed CRS, thereof $6 \%$ grade 3 and no grade 4 or 5 ; neurologic side effects occurred in $42 \%$ of the patients and only one patient (3\%) developed a grade 4 ICANS. Respecting efficacy, ORR was $85 \%$, with $45 \%$ of patients achieving $\geq \mathrm{CR}$. At doses $\geq 150 \times 10^{6}(N=30)$, ORR was $90 \%$ with $50 \%$ of patients achieving $\geq \mathrm{CR}$. A total of 16 patients who achieved a response were evaluated for MRD status in the bone marrow. All 16 patients were MRD-negative at a threshold of at least $10^{-4}$ nucleated cells. Responses appeared independent of sBCMA or tumor BCMA levels. After a median follow-up of 11.3 months, the mPFS in the $\geq 150 \times 10^{6}$ cohort was 11.8 months. Persistence of bb2121 at 6 and 12 months was detected in 57 and $20 \%$ of patients, respectively, and blood CAR T-cell levels were higher in patients who achieved a response (51). Due to these results, a confirmatory single-arm phase II trial (KarMMa; NCT03361748) enrolled 140 patients, of whom 128 patients received the product. The latest results were presented at the last ASCO meeting. Patients were treated at target dose levels of 150-450 x10 ${ }^{6}$ CAR T-cells, $84 \%$ were triple refractory (PI, IMiD and anti-CD38 antibody) and $35 \%$ had high-risk cytogenetic profile. The safety results were consistent with the CRB-401 trial. CRS was observed in $84 \%$ of all patients with five, one, and one grade 3, 4 , and 5 events, respectively. ICANS occurred in $18 \%$ of patients (grade $\geq 3$ in $3 \%$ ). Regarding efficacy results, the ORR was $73 \%$ with $33 \%$ of patients achieving $\geq \mathrm{CR}$. Clinically meaningful efficacy was observed across subgroups including high-risk cytogenetics and patients with extramedullary disease. After a median followup of 13.3 months, mDOR, mPFS, and mOS were 10.7, 8.8, and 19.4 months, respectively. Efficacy was highest at the target dose of $450 \times 10^{6}$ CAR T-cells (ORR of $82 \%$ including $39 \%$ CR; mDOR and mPFS of 11.3 and 12.1 months, respectively) $(52,53)$. In addition, a phase III trial (KarMMa-3; NCT03651128) comparing the efficacy and safety of bb2121 vs. standard triplet regiments in RRMM and (71) clinical trials analyzing the use of this CAR in the second- (KarMMa-2; NCT03601078) or first-line (KarMMa-4; NCT04196491) treatment in high-risk MM patients are underway $(72,73)$.

\section{bb21217}

Bluebird bio's bb21217 CAR uses the same CAR molecule as bb2121 (70), however, bb21217 is cultured with the phosphoinositide 3-kinase (PI3K) inhibitor bb007 during the manufacturing process, thereby increasing memory-like T-cells $\left(\mathrm{CD}_{2} \mathrm{~L}^{+}\right.$and $\left.\mathrm{CD}^{+} 7^{+}\right)$in order to improve persistence of the CAR T-cells $(74,75)$. Preliminary results of the phase 1 CRB-402 trial (NCT03274219) were recently presented at ASH. During dose-escalation phase, enrollment was restricted to patients with $\geq 50 \%$ BCMA expression on malignant plasma cells. Lymphodepletion protocol was comparable to bb2121 and escalating doses of $150 \times 10^{6}, 300 \times 10^{6}$, and $450 \times$ $10^{6}$ CAR T-cells were being tested. Data were presented from 33 heavily pretreated MM patients. CRS and ICANS were observed in $66 \%$ of the patients $(6 \%$ were grade $\geq 3$ and one CRS-RM) and $24 \%$ of the patients ( $8 \%$ were grade $\geq$ 3 ), respectively. The ORR in the first three dose steps were as follows: $83 \%$ ( $\geq$ CR 33\%), 43\% ( $\geq$ CR 0\%), and $57 \%$ ( $\geq$ CR 14\%), respectively. Long-term CAR T-cell persistence was observed in 8/10 evaluable patients at month 6 and $2 / 2$ at month 18. The dose-expansion phase is currently ongoing to further explore the $450 \times 10^{6}$ CAR T-cell dose (54). Initial efficacy results of this next-generation anti-BCMA CAR T-cell are encouraging. The increased proportion of memory-like Tcells has the potential to prolong CAR T-cell persistence and improve potency, however, confirmatory long-term results are still pending.

\section{JCARH125 (Orvacabtagene Autoleucel)}

JCARH125 is an anti-BCMA CAR T-cell product with a fully human $\mathrm{scFv}$ and $4-1 \mathrm{BB}$ costimulatory domain. It also contains a truncated epidermal growth factor receptor (EGFRt) as a selection marker and safety switch. The construct has shown minimal tonic signaling reducing antigen-independent exhaustion and it is not inhibited by sBCMA. The manufacturing process is optimized for a defined composition of purified $\mathrm{CD} 4^{+}$ and $\mathrm{CD}^{+}$CAR T-cells enriched for central memory phenotype cells (76). The phase 1/2 EVOLVE trial (NCT03430011) is currently ongoing. Lymphodepleting chemotherapy consists of Cy and Flu before a single dose of JCARH125 is administered. The first three dose levels evaluated in the dose-escalation phase were 50 and $150 \times 10^{6}$ CAR T-cell. Data on 44 RRMM patients with a median follow-up of 11 weeks was presented. CRS was observed in $80 \%$ of patients, CRS grade $\geq 3$ in $9 \%$, while neurological events were presented in $25 \%$ of patients, grade $\geq$ 3 in $7 \%$. The ORR in the entire cohort was $82 \%$ ( $\geq$ CR 27\%) (55). Updated results in 62 patients treated with JCARH125 at higher dose levels of 300,450 , and $600 \times 10^{6}$ CAR T-cells were recently presented at ASCO. $41 \%$ had high-risk cytogenetic profile and $94 \%$ were triple-refractory. CRS was observed in $89 \%$, CRS grade $\geq 3$ in $3 \%$ and neurotoxicity was seen in $13 \%$ and grade $\geq 3$ in $3 \%$. Regarding efficacy results, the ORR was 92 and $36 \%$ achieving $\geq$ CR across all dose levels and after a median follow-up of 9.5 months, the mPFS in the $300 \times 10^{6}$ CAR T-cell cohort was 9.3 months (56). Early data reported for this product characterized by a fully human binder, enrichment of central memory cells, and reduced T-cell exhaustion, are promising. It is estimated that recruitment of the phase 2 trial will be completed in 2021.

Currently, there are preliminary data of other ongoing studies, especially in China, which are listed in Table 1. Although data from all these studies are heterogeneous, with differences on patient population, CAR constructs, lymphodepletion protocols, CAR T-cell doses, and grading scales of toxicities, BCMA CAR T-cells showed impressive results achieving deep responses in heavily pretreated MM patients. Nevertheless, there are different caveats regarding the use of CAR T-cells targeting BCMA, for example, the relevance of the heterogeneous BCMA expression on 
myeloma cells, the impact of sBCMA on the effectiveness of the therapy, and the relapses observed during the followup of most patients. Another aspect to highlight is that for most CAR T-cell trials targeting BCMA, the incidence of severe CRS and ICANS is considerably lower as compared to treatment with CD19 CAR T-cells in B-cell malignancies. However, the mechanism of these differences is yet to be elucidated $(77,78)$.

\section{CD19}

Although widely expressed in B-cell malignancies, CD19 expression in MM is limited. Nevertheless, CD19 CAR T-cells have been effective in a subset of patients. Garfall et al. published the results of a pilot study in which $10 \mathrm{MM}$ patients with early relapse after a first ASCT received a second ASCT followed by CD19 CAR-T cells (CTL019) (79). CD19 expression on myeloma cells by flow cytometry was $<2 \%$ in all evaluable patients and negative in 2 subjects. However, an ORR was achieved in 8 patients at 100 days after ASCT (including 1 sCR, 4 VGPR, and $2 \mathrm{PR}$ ). Two patients experienced longer PFS after ASCT + CTL019 compared to their previous ASCT, a so called "remission inversion," suggesting a potential benefit of CD19 CAR T-cell following high-dose melphalan. This might be due to the fact that a significant fraction of myeloma cells expresses CD19 at molecular density which is detectable by direct stochastic optical reconstruction microscopy (dSTORM) but not by flow cytometry (80). Interestingly, less than 100 CD19 molecules are required for myeloma cell detection by CD19 CAR T-cells. In addition, evidence of a less differentiated MM subclone $\left(\mathrm{CD} 19^{+} \mathrm{CD} 138^{-}\right)$with drug-resistance and disease propagating properties has emerged $(81,82)$. Despite these encouraging findings, the use of CD19 CAR T-cells as a potential treatment for MM needs to be further explored. Data from an ongoing phase II clinical trial (NCT02794246) of CD19 CAR Tcell as maintenance therapy in RRMM are expected to provide further insights.

Further evidence supporting a role of CD19 CAR T-cells in MM might come from multi-antigen specific CAR T-cell products. Preclinical ex vivo experiments showed that myeloma cell depletion was enhanced when CD19 CAR T-cells were tested in combination with BCMA CAR-T cells (79). In a clinical trial, Yan et al. showed that 17 out of 21 patients with RRMM achieved good and durable responses after CD19 and BCMA CAR T-cell infusion (83). Results from the SZ-CARTMM02 study (NCT03455972) presented by Shi et al. during the 45th meeting of European Blood and Marrow Transplantation (EBMT) further supported multi-antigen targeting CAR Tcell therapy in MM. The trial demonstrated that BCMA and CD19 CAR T-cell infusions can be applied as consolidation therapy after tandem ASCT to increase in-depth responses in newly diagnosed (ND) MM patients with high risk features. ORR was $100 \%$ with 4 sCR, 3 CR, and 3 VGPR after CAR-T cell infusion. Of four patients in PR after ASCT, 3 achieved VGPR and 1 sCR after CAR T-cell infusion (84). Nevertheless, the additive role of CD19 CAR T-cells needs to be investigated in a randomized study that includes a respective control arm (e.g., BCMA CAR T-cell therapy alone). In this regard, a clinical trial comparing BCMA CAR Tcells alone or in combination with CD19 CAR T-cells is ongoing (NCT03549442).

\section{SIGNALING LYMPHOCYTIC ACTIVATION FAMILY MEMBER 7 (SLAMF7)}

SLAMF7 (CS1, CD319, CRACC) is a member of the signaling lymphocytic activation family receptors involved in the regulation of the immune system. SLAMF7 is highly expressed on malignant plasma cells both, in NDMM and RRMM, regardless of the cytogenetic risk stratification (85). A prior study suggests that SLAMF7 has a role in MM cell survival via interaction with the bone marrow stromal niche (86). Intriguingly, pre-malignant stages such as monoclonal gammopathy of undetermined significance and smoldering myeloma retain SLAMF7 expression $(85,87)$. SLAMF7 is also reported on immune cells, including NK-cells, a subset of T-cells, activated B-cells, dendritic cells and macrophages where it mediates activating or inhibitory functions through intracellular adaptor proteins (88-90). Conversely, hematopoietic stem cells or other solid organ tissues do not express SLAMF7, making it a candidate antigen for immunotherapy. The use of the anti-SLAMF7 antibody elotuzumab in combination with lenalidomide demonstrated efficacy without significant toxicity (91). Therefore, SLAMF7 has been investigated as potential target for CAR T-cell therapy. Our group demonstrated that SLAMF7 CAR T-cells generated from healthy donors and MM patients are able to eradicate either medullary or extramedullary disease in a murine xenograft model (92). Responses were durable and OS was improved. Generation of SLAMF7 CAR T-cells might be challenging due to expression of SLAMF7 on T-lymphocytes. However, it should be noted that SLAMF7 CAR T-cells acquire a SLAMF7-/low phenotype after CAR transduction allowing them to escape from fratricide and to expand to clinically relevant doses (92). Following these results, SLAMF7 CAR T-cell therapy set foot into clinical trials (NCT03710421, NCT04142619, EudraCT Nr.2019-001264-30/CARAMBA-1). The CARAMBA project is a phase $1 / 2$ clinical trial funded from the European Union's Horizon 2020 program and a key innovation of the study relies on the use of a Sleeping Beauty (SB) transposon system as strategy for CAR T-cell engineering. As compared to viral vectors, $\mathrm{SB}$ transposition from minicircles vectors provides similar long-lasting transgene expression, superior safety profile and lower manufacturing cost, addressing the challenge of expanding CAR T-cell therapy on global scale $(93,94)$. To manage undesired toxicity following infusion, this product is equipped with an EGFRt safety switch. In the ongoing NCT04142619 trial, MM patients receive universal "off-theshelf" SLAMF7 CAR T-cells which contain an inactivation of the TCR $\alpha$ constant (TRAC) gene using transcription activator-like effector nuclease (TALEN) gene-editing technology (95). To prevent self-antigen-driven fratricide, SLAMF7 disruption was included as an additional step during manufacturing. 


\section{CD44v6}

CD44v6 is an isoform of the hyaluronate receptor CD44 expressed in MM, acute myeloid leukemia and solid tumors, where it plays a role in tumor growth and dissemination. In MM, $\mathrm{CD} 44 \mathrm{v} 6$ is associated with poor prognosis (deletion of 13q14), advanced disease and high-risk features (96). Unlike CD44, the expression of the v6 isoform is relatively tumor-restricted with minimal expression on keratinocytes, activated T-cells and monocytes. Conversely, it is not expressed on hemopoietic stem cells. Casucci et al. reported remarkable antimyeloma effects of CD44v6 CAR T-cells in a mouse xenograft model (97). Only mild and reversible monocytopenia was reported. In this respect, it should be noted that monocyte depletion might have an unexpected benefit since monocytes are the major source of cytokines responsible for CRS and neurotoxicity (98). Bivatuzumab is a mAb tested in a phase 1 clinical trial to direct mertansine activity to CD44v6 expressing solid tumors (99). Although PR has been observed, the trial was discontinued due to severe skin toxicity. Interestingly, Casucci et al. did not observe significant skin-related toxicity after CD44v6 CAR Tcell infusion, potentially because hair follicles represent immuneprivileged sites. In addition, CD44v6 CAR T-cell fratricide was not observed. Following these promising results, a first-inhuman phase $1 / 2$ a clinical trial in RRMM patients treated with CD44v6 CAR T-cells has been registered and it is currently recruiting participants (NCT04097301). The incorporation of a transduction marker (nerve-growth-factor receptor/NGFR) into the transgene allows for CAR T-cell enrichment prior to infusion. Moreover, NGFR can be used to track CAR T-cell in vivo to establish expansion and persistence during the followup of the patient. To ascertain safety, the HSV-TK Mut2 suicide gene has been included as a safety switch in case of undesired toxicity (100).

\section{CD138}

CD138 is highly expressed in NDMM and RRMM where it promotes tumor growth (101). Although CD138 is broadly expressed in human tissues, CD138 targeting CAR T-cell therapy reportedly favorable toxicity profile but only modest anti-MM efficacy $(9,102)$. Moreover, immune escape by antigen loss has been reported (103). Therefore, combination of CAR T-cell products against different antigens (CD138 plus BCMA/CD19/CD56/CD38) is currently explored in several clinical trials (NCT03196414, NCT03473496, NCT03271632).

\section{NATURAL KILLER GROUP2, MEMBER D (NKG2D) LIGANDS}

Although NKG2D CAR-T cells showed to be effective in a preclinical study against MM cells (104), Baumeister et al. reported no objective response in 5 patients with RRMM treated with first generation NKG2D CAR T-cells (105). This might be explained by the fact that first-generation
CAR T-cells have very limited anti-tumor efficacy and persistence. Second, the omission of lymphodepletion therapy may have compromised the engraftment and further limited their expansion. However, no adverse events have been reported. The inclusion of a co-stimulatory domain into the CAR construct and the use of conditioning regimen prior to infusion might scale out NKG2D CAR T-cells efficacy.

\section{IMMUNOGLOBULIN LIGHT CHAINS}

B-cell aplasia is a well-known on-target, off-tumor toxicity observed after CD19 CAR T-cell infusion. Targeting antigens that have a more restricted distribution might prevent B-cell depletion. As mature B-cells express either $\kappa$ or $\lambda$ light chains, but not both, Ramos et al. showed that $\kappa$-directed CAR Tcells might be a promising treatment for B-cell neoplasms, limiting undesired adverse events (10). Although plasma cells generally secrete and do not retain Igs on their surface, myeloma propagating cells expressing surface Igs have been described (106). Therefore, light chains can be a potential CAR target also for MM. In this regard, an anti- $\kappa$ free light chain $\mathrm{mAb}$ was investigated in clinical trials with good responses (107). Unfortunately, $\kappa$-directed CAR T-cells did not show discernible responses in 7 patients with $\kappa$ restricted MM (10).

\section{CD38}

CD38 is highly and uniformly expressed on myeloma cells, making it a candidate target for MM. Several mAbs targeting $\mathrm{CD} 38$ demonstrated clinical efficacy and daratumumab has been approved for the treatment of $\operatorname{NDMM}(108,109)$ and RRMM (110-112). Unfortunately, CD38 is also expressed on hematopoietic stem cells, myeloid precursors, and solid tissues including the nervous system (113). Consequently, on-target, off-tumor toxicity might challenge CD38 CAR T-cell therapy. To overcome this issue, several strategies have been proposed. For example, low affinity CD38 CAR T-cells generated through light-chain exchange technology have shown enhanced capacity to discriminate between tumors and CD38 low healthy tissues (114). Also, the incorporation of safety mechanisms into the CAR construct such as caspase9-based suicide genes (115) or tetracycline inducible CAR design (116) might be a tool to limit off-tumor effects. CD38-targeted CAR T-cells are currently under investigation as a monotherapy for RRMM patients (NCT03464916) or in combination with CD19 (NCT03125577) and BCMA (NCT03767751). Interestingly, a novel antigen receptor structure called dimeric antigen receptor (DAR) targeting CD38 has been designed and delivered into T-cells with a single step non-viral knock-out/knock-in (KOKI) methodology. Preclinical results suggest that DAR-T-cells exhibited a higher cytotoxicity against tumor cells as compared to CAR T-cells (117). 


\section{G PROTEIN-COUPLED RECEPTOR CLASS C GROUP 5 MEMBER D (GPRC5D)}

GPRC5D is widely expressed in MM cells and is associated with poor prognosis (118). Preclinical studies have suggested GPRC5D as promising target for MM (119, 120). Although GPRC5D is expressed in the hair follicle, no skin toxicity was reported in a preclinical model (120). Since GPRC5D expression is independent of BCMA, BCMA/GPRC5D dualtargeted CAR T-cells have recently been demonstrated as a strategy to mitigate BCMA escape-mediated relapse in a xenograft mouse model (121). Consequently, a phase 1 clinical trial of GPRC5D CAR-T cell therapy in patients who had prior BCMA CAR-T cell therapy has been registered (MCARH109).

\section{CD56}

CD56 is highly expressed in myeloma cells but not in normal plasma cells (122). CD56 expression on central and peripheral nervous system entails concerns for neurologic toxicity. In earlyphase clinical trial, the anti-CD56 immunotoxin lorvotuzumab mertansine showed modest activity in 37 RRMM patients, but related peripheral neuropathy was observed in about $50 \%$ of patients (123). Intriguingly, no serious adverse events have been reported in a case report evaluating CD56 CAR Tcell therapy for rhabdomyosarcoma (124). CD56 CAR Tcells have been shown effective against myeloma cells in a preclinical study (125). Therefore, CAR T-cell therapy targeting CD56 has paved the way for clinical trials in combination with another target antigen, including BCMA (NCT03473496, NCT03271632).

\section{NEW YORK ESOPHAGEAL SQUAMOUS CELL CARCINOMA 1 (NY-ESO-1)}

The cancer-testis antigen NY-ESO-1 is expressed in a wide variety of malignant neoplasms (126). A study of gene expression profiling conducted on bone marrow biopsies from MM patients revealed that NY-ESO-1 is expressed in $60 \%$ of patients at diagnosis and in 100\% at relapse, especially in patient with poor prognosis $(127,128)$. In addition, $10 \%$ of MGUS and smoldering MM are NY-ESO-1 positive (128). Conversely, NYESO-1 is not expressed on normal tissues, making it a suitable candidate for immunotherapy. As intracellular target, NY-ESO-1 is detected only by TCRs and clinical efficacy of NY-ESO-1 TCRengineered T-cells in MM patients have been reported (129131). Interestingly, Schubert et al. managed to make NY-ESO1 suitable for CAR detection by generating a construct which recognizes the NY-ESO-1/HLA complex on the tumor surface (13). NY-ESO-1 CAR T-cells showed to be effective against myeloma cells in vitro (13). A phase $1 / 2$ clinical trial to evaluate safety and effectiveness of NY-ESO-1 CAR T-cells in MM has been registered (NCT03638206). Data from clinical trials of CAR T-cells beyond BCMA are summarized in Table 2.

\section{PRECLINICAL DATA}

Several new targets are currently under investigation for the treatment of MM, including integrin $\beta 7$ and CD229. Significant efforts have been made to expand the pool of potentially targetable antigens. One of the most interesting strategies relies on the identification of neoantigens generated by posttranslational events (such as conformational changes). In this perspective, the activated conformation of integrin $\beta 7$ has been selected as potential immunotherapeutic target for MM (134). Hosen et al. have developed a mAb (MMG49) that detects an epitope exposed only in the active state of integrin $\beta 7 . \mathrm{T}$ cells transduced with a MMG49-derived CAR exert anti-MM effects without on-target, off-tumor toxicity (since the inactive state of integrin $\beta 7$ is not targeted by CAR T-cells) (134). Therefore, a clinical trial to evaluate MMG49 CAR-T cells is expected (134).

CD229 (also known as SLAMF3) is strongly expressed in NDMM and RRMM patients (135). Intriguingly, CD229 is expressed on myeloma-precursor cells responsible for the relapse after treatment. CD229 CAR-T cells have been developed and tested in pre-clinical studies with promising results $(136,137)$.

\section{MECHANISMS OF RESISTANCE TO CAR T-CELL THERAPY IN MYELOMA AND STRATEGIES TO OVERCOME THESE}

Despite the recent advances, there are still many questions to be addressed. A meta-analysis of 15 CAR T-cell trials in MM presented at ASH 2019 revealed an ORR of 82\%, a pooled relapse rate of $45 \%$ and a mPFS of 10 months (138). Reasons why patients relapse or fail to respond include T-cell and tumor cell intrinsic factors. While idecabtagene vicleucel is racing for approval to become the first-in-class CAR T-cell product for treatment of MM, various approaches are tested clinically and preclinically to overcome these mechanisms of resistance and improve clinical efficiency further (Figure 2).

\section{T-CELL DIRECTED STRATEGIES TO IMPROVE PERSISTENCY, POTENCY AND PENETRATION CAPACITIES OF CAR T-CELLS}

\section{Refinement of the CAR Construct Human scFvs}

To improve T-cell functionality, one focus is undoubtedly on the refinement of the CAR construct. One milestone toward successful clinical application of CAR T-cells was the recognition that immune rejection responses against the genetically modified T-cells led to reduced persistence and impaired efficacy (139). Ever since, preclinical efforts have been made to reduce the immunogenicity of CAR T-cell by replacing CAR construct components of non-human or partially human nature with fully humanized constructs (140). This has been facilitated by 
TABLE 2 | Selected non-BCMA CAR T-cell clinical trials in multiple myeloma.

\begin{tabular}{|c|c|c|c|c|c|c|c|}
\hline Registration number & Antigen & $\mathbf{N}$ & $\begin{array}{l}\text { CAR construct } \\
\text { specification }\end{array}$ & $\begin{array}{l}\text { Lymphodepletion } \\
\text { protocol }\end{array}$ & CAR T-cell dose & Response & $\begin{array}{l}\text { CRS (grade } \geq 3 \text { ) } \\
\text { CRS-related } \\
\text { mortality ICANS } \\
\text { (grade } \geq 3\end{array}$ \\
\hline NCT02135406 (79) & CD19 & 10 & $\begin{array}{l}\text { Lentivirus } \\
4-1 B B \\
\text { scFv NA }\end{array}$ & $\mathrm{HDM}+\mathrm{ASCT}$ & $1-5 \times 10^{7}$ & $\begin{array}{l}\text { Response at d100 } \\
\text { post-ASCT: } \\
\text { ORR } 70 \% \text { ( } \geq \text { CR 50\%) }\end{array}$ & $\begin{array}{l}\text { CRS 10\% (0\%) } \\
\text { CRS-RM 0\% } \\
\text { ICANS 0\% }\end{array}$ \\
\hline NCT03455972 (84) & CD19 + BCMA & 10 & $\begin{array}{l}\text { Lentivirus } \\
\text { OX40-CD28 } \\
\text { scFv murine }\end{array}$ & Cy/Bu + ASCT & $\begin{array}{l}\text { CD19 CAR T-cell: } 1 \times \\
10^{7} / \mathrm{kg} \\
\text { BCMA CAR T-cell: } 1 \times \\
10^{7} / \mathrm{kg}\end{array}$ & $\begin{array}{l}\text { Response after ASCT: } \\
\text { ORR 100\% ( } \geq \text { CR 70\%) }\end{array}$ & $\begin{array}{l}\text { CRS 100\% (0\%) } \\
\text { CRS-RM 0\% } \\
\text { ICANS 0\% }\end{array}$ \\
\hline NCT02203825 (105) & NKG2D ligands & 5 & $\begin{array}{l}\text { Retrovirus } \\
\text { scFv human }\end{array}$ & None & $1 \times 10^{6}-3 \times 10^{7}$ & ORR 0\% & $\begin{array}{l}\text { CRS 0\% } \\
\text { CRS-RM 0\% } \\
\text { ICANS 0\% }\end{array}$ \\
\hline NCT00881920 (10) & $\kappa L C$ & 7 & $\begin{array}{l}\text { Retrovirus } \\
\text { CD28 } \\
\text { scFv murine }\end{array}$ & $\begin{array}{l}\text { Cy }(57 \%) \\
\text { None (43\%) }\end{array}$ & $0.92-1.9 \times 10^{8} / \mathrm{m}^{2}$ & ORR 0\% & $\begin{array}{l}\text { CRS 0\% } \\
\text { CRS-RM 0\% } \\
\text { ICANS 0\% }\end{array}$ \\
\hline $\begin{array}{l}\text { NCT03287804/AUTO2 } \\
\text { (133) }\end{array}$ & $\begin{array}{l}\text { APRIL-CAR T-cell } \\
\text { against TACl and } \\
\text { BCMA }\end{array}$ & 12 & $\begin{array}{l}\text { Retrovirus } \\
\text { CD28 - OX40 } \\
\text { ScFv }\end{array}$ & $\mathrm{Cy} / \mathrm{Flu}$ & $15-900 \times 10^{6}$ & ORR 43\% ( $\geq$ CR 0\%) & $\begin{array}{l}\text { CRS 45\% (0\%) } \\
\text { CRS-RM 0\% } \\
\text { ICANS 0\% (0\%) }\end{array}$ \\
\hline
\end{tabular}

APRIL, A Proliferation Inducing Ligand; ASCT, autologous stem cell transplantation; AST, aspartate aminotransferase; Bu, busulfan; BCMA, B-cell maturation antigen; Cy, cyclophosphamide; CR, complete remission; CRS, cytokine-release syndrome; CRS-RM, CRS related-mortality; Flu, fludarabine; HDM, high-dose melphalan; ICANS, immune effector cell-associated neurotoxicity syndrome; кLC, kappa light chain; NA, not available; ORR, overall response rate; PCD, pomalidomide-cyclophosphamide-dexamethasone; scFv, single-chain variable fragment; TACl, transmembrane activator, calcium modulator, and cyclophilin ligand interactor; VAD, vincristine-doxorubicin-dexamethasone.

technical advances such as the availability of human B-cell derived $s c F v$ phage display libraries. One of the first CAR T-cell products for treatment of MM incorporating a fully human antiBCMA CAR was developed at MSKCC (76) and has recently been tested clinically as MCARH171 (NCT03070327). Another anti-BCMA CAR T-cell product with a fully human antigen binding domain is the FHVH-BCMA-T containing a heavychain-only antigen recognition domain $(64,65)$. This product is currently under clinical evaluation at the NIH (NCT03602612). Treatment with CT103A (63) (ChiCTR1800018137), a third fully human anti-BCMA CAR T-cell developed by Nanjing IASO Biotherapeutics, was shown to be effective even in patients relapsing after previous CAR T-cell therapy. The elimination of non-human CAR components has thus the potential to break the paradigm to never consider a second dosing of CAR T-cells.

\section{High-Affinity Binding/Tuned Affinity}

Besides reduced immunogenicity, other characteristics of the targeting moiety are essential for optimal CAR T-cell functionality. These include binding affinity to the antigen, location of the epitope and potentially various other factors (76). In addition to extensive screening analyses of $\mathrm{scFv}$ libraries, one approach to generate high-affinity CARs can be the development of dual epitope binding moieties as incorporated in the LCAR-B38M (Legend-2, NCT03090659) (45).

\section{Reduction of Tonic Signaling}

Another aspect of considerable relevance for the engineering of the CAR construct is the prevention of tonic signaling (141). While low-level TCR tonic signaling represents a physiological process to regulate non-activated T-cells, ligand-independent CAR tonic signaling leads to uncoordinated activation with detrimental effects on CAR functionality. Reasons for increased CAR tonic signaling can be found in the CAR structure. First, the targeting moieties of the CAR often display reduced stability and are therefore at risk of oligomerization or clustering, leading to continuous off-target signaling and development of an exhausted T-cell phenotype (142). While it is yet controversial whether the choice of a defined co-stimulatory domain can reverse CAR tonic signaling (142-144), an attractive option to reduce the likelihood 


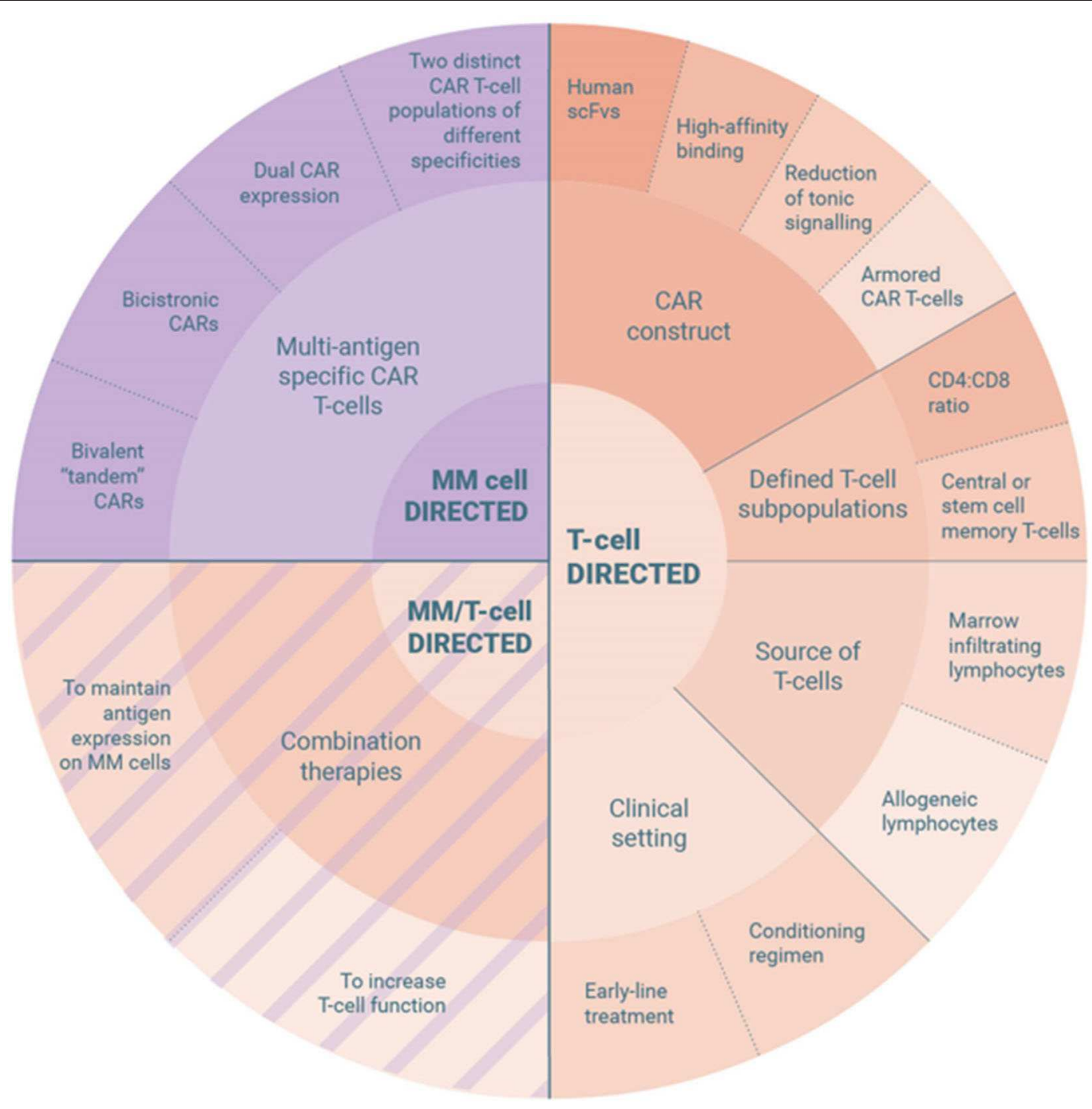

FIGURE 2 | Strategies to overcome resistance mechanisms to CAR T-cell therapy in multiple myeloma.

of CAR oligomerization or clustering is the use of alternative targeting moieties, such as centyrinsTM, small monomeric proteins based on a consensus tenascin fibronectin domain (145). One such centyrinTM-based CAR T-cell product is the P-BCMA101 currently under clinical investigation (NCT03288493) (59, 60 ). Second, the design of the hinge and spacer domain is crucial for the prevention of tonic signaling, especially when full length IgG derived spacers are incorporated, because those spacers bare the risk of Fc $\gamma$ R-mediated interactions $(146,147)$. Adjusting the hinge and spacer design by replacement of the $\mathrm{N}$-glycosylation site responsible for Fc $\gamma$ R-binding has been shown to restore CAR T-cell functionality (147). Albeit their use is largely empirical, most MM trials rely on CAR constructs incorporating CD8 $\alpha$ derived spacers $(50,67,76)$ where the problem of optimal immune synapse appears to be less pronounced.

\section{Armored CAR T-Cells}

Still in its infancy but of considerable clinical potential is the generation of armored CAR T-cells. As in MM the microenvironment can promote immune escape of the tumor cells, armored CAR T-cells are equipped with additional features to overcome the immunosuppressive nature of the MM niche. Examples are CAR T-cells that constitutively express the immune-stimulatory CD40 ligand to prevent antigen loss and induce an endogenous anti-tumor immune response (148) or CAR T-cells that secrete a PD-1 blocking $\mathrm{scFv}$ and thus increase antitumor efficacy of both, CAR T-cells and tumor-specific bystander T-cells (149). Conceptually attractive, the clinical relevance of such armored CAR T-cells has yet to be demonstrated. 


\section{SELECTION OF DEFINED T-CELL SUBPOPULATIONS}

While in the first clinical trials, patients received CAR Tcell products comprising random compositions of T-cell subpopulations, evidence has been growing that efficiency and especially persistency can be enhanced through a tailored composition of T-cell subsets (150). Further, it has been demonstrated that enrichment of non-cycling, non-activated early memory $\mathrm{CD} 8^{+} \mathrm{T}$-cells and $\mathrm{CD} 4^{+} \mathrm{T}$-cells with early memory features in pre-manufacturing cells is a predictive biomarker of response to BCMA CAR T-cells in MM patients (151). On this basis, various approaches are currently investigated clinically for treatment with BCMA CAR T-cells: For example, the $\mathrm{CD} 4^{+} / \mathrm{CD}^{+}$ratio is adjusted to $1: 1$, before gene transfer in the JCARH125 product (NCT03430011) (55) or after gene transfer in the FCARH143 product (NCT03338972) (58), to avoid heterogeneity of the therapeutic agent between patients and to enable enhanced potency through optimized $\mathrm{CD} 4^{+}$ CAR T-cell help to the $\mathrm{CD}^{+}$CAR T-cells (150). During generation of bb21217, a follow-on product of bb2121, the PI3K inhibitor bb007 is added to enrich for memory-like T-cells (NCT03274219) (54), because self-signaling by the CAR $\mathrm{CD} 3 \zeta$ moiety drives constitutive PI3K activation that favors T-cell terminal differentiation via AKT and mTOR pathways (152). And, although the precise mechanism is still unclear, viral-free generation of the P-BCMA-101 product makes use of the piggyBac ${ }^{\circledR}$ transposon-based DNA modification system that favors the development of a T-stem cell memory phenotype (NCT03288493) $(59,60)$. However, the eventual clinical benefit of the different strategies to specifically engineer products of a desirable T-cell subset composition remains unclear to date, because follow-up periods are still too limited to assess durability of responses.

\section{SOURCE OF CAR T-CELLS}

Another approach to obtain T-cells with favorable properties for CAR T-cell generation is the use of bone marrow derived T-cells, termed MILs (marrow-infiltrating lymphocytes) (153). MILs display enhanced memory phenotype, higher $\mathrm{CD}^{+} / \mathrm{CD} 4^{+}$ratio and better ability to persist long-term (154) and MILs that were genetically modified to express a CAR demonstrated improved antimyeloma efficacy and reduced phenotypic exhaustion in vitro.

The use of allogeneic lymphocytes for the manufacture of CAR T-cells primarily targets the logistical and financial constraints of autologous CAR T-cell therapy, but also represent a source of T-cells with reduced prior exposure to anti-myeloma therapy. The availability of advanced strategies for gene editing, such as CRISPR-Cas9 technology (155) or TALEN-mediated approaches (156), have been key for the required genetic modifications to provide "off-the-shelf" CAR T-cells; such as the elimination of the $\alpha \beta$ T-cell receptor to reduce the potential of severe graft-vs.-host disease of allogeneic T-cells or to knock-out the CD52 gene to enable selective lymphodepletion of host lymphocytes by alemtuzumab (157). Different BCMA-directed products have been designed, such as ALLO-715 characterized by TALEN-disrupted TCR- $\alpha$ chain and CD52 loci (158), and P-BCMA-ALLO1 that lacks the endogenous T-cell receptor and $\beta$-2 microglobulin (159). The SLAMF7-directed "off-theshelf” CAR T-cell product termed UCARTCS1 with inactivated TCR- $\alpha$ chain locus and SLAMF7 gene knock-out to reduce fratricide of SLAMF7 positive CAR T-cells (95), is currently investigated clinically in the MELANI-01 trial (NCT04142619). Another promising, protein-based, option to generate TCRdepleted CAR T-cells in a single viral transduction step is the incorporation of a TCR-directed $\mathrm{scFv}$ with an endoplasmatic reticulum-retention domain (TCR-KDEL) (160), and clinical testing is on the way. If efficacy and safety of CAR T-cell products generated from healthy donor lymphocytes prove comparable to autologous products, the "off-the-shelf" approach has the potential to facilitate CAR T-cell delivery significantly in the future.

\section{CLINICAL SETTING OF CAR T-CELL THERAPY}

\section{Conditioning Therapy}

For over a decade, it has been common understanding in the field, that efficacy of adoptive T-cell therapy can be significantly enhanced by prior lymphodepletion. Mechanisms proposed at the time were the elimination of immunosuppressive regulatory T-cells (161) and cellular "sinks" for homeostatic cytokines (162). Recent data suggest that there are further biological effects to the conditioning regimen than the sole lymphodepletion that impact responses to CAR T-cell therapy in Non-Hodgkin lymphoma (163). The beneficial effects of conditioning therapy prior to adoptive T-cell transfer have also been observed in the field of MM (50), even if a variety of regimens with regards to drugs, timing and dosing is being used in the different clinical trials. Studies to elucidate the exact effects of the conditioning treatment are therefore warranted to optimize conditioning regimens further (164).

\section{CAR T-cell Therapy as Earlier Intervention During MM Disease}

$\mathrm{MM}$ is associated with adverse changes in the T-cell repertoire $(165,166)$ and many anti-myeloma therapies are detrimental to the lymphatic cells. A recent study performed at the University of Pennsylvania provides data for the hypothesis that CAR Tcell products generated from leukapheresis samples collected after first line induction therapy would be of greater clinical potential as compared to samples collected from RRMM patients (167). In fact, as safety has been demonstrated for a variety of BCMA CAR T-cell products in phase 1 clinical trials, the evaluation of CAR T-cell therapy at earlier time points during the course of MM disease appears promising. More recent clinical studies like KarMMa-2 (NCT03601078; inclusion of patients with 
1 prior line of therapy and high-risk factors), CARTITUDE2 (NCT04133636; 1-3 prior lines of therapy), and KarMMa-4 (NCT04196491; first-line treatment in high-risk MM patients) are currently putting this hypothesis to the test and results are eagerly awaited.

\section{COMBINATION THERAPY TO IMPROVE EFFICACY OF CAR T-CELLS}

The concept of combination therapies in MM dates back to the last century (168), thus it is not surprising that various efforts are made to identify suitable immunomodulatory drugs for combination with CAR T-cell treatment. Preclinical analyses demonstrated that the addition of lenalidomide during CAR T-cell generation (169) or functional testing (170) enhanced anti-tumor activity of the CAR T-cell product. Besides effects on T-cells and other immune cells, lenalidomide has direct anti-myeloma properties and therefore appears a promising combination partner for CAR T-cell therapy of MM. First trials with BCMA CAR T-cells are evaluating this concept clinically (NCT03070327, NCT04133636).

A clinical observation provided a proof-of-principle for PD-1 blockade as another possible, primarily T-cell directed, combination drug for CAR T-cell therapy (171). In a small case series, one out of five patients who progressed after BCMA CAR T-cell therapy experienced significant, yet transient, expansion of CAR T-cells during pembrolizumab-based salvage treatment. Another instructive clinical observation was reported for a patient who required radiotherapy due to spinal cord compression shortly after BCMA CAR Tcell therapy (172). This patient experienced expansion of his TCR repertoire and durable systemic response not exclusively attributable to radiotherapy, suggesting an abscopal-like synergism between radiotherapy and CAR T-cell treatment.

\section{TUMOR DIRECTED STRATEGIES TO REDUCE ANTIGEN LOSS}

Besides adequate cellular functionality, a crucial prerequisite of effective CAR T-cell therapy is the maintenance of relevant antigen expression levels on the tumor surface (173). Interestingly, it is especially in patients with long persistence of CAR T-cells that antigen-negative/low variants have been observed. In clinical trials with CD19 CAR T-cells for treatment of B-cell malignancies, up to $25 \%$ of patients with complete remission relapsed with CD19 negative disease (2). This observation is commonly referred to as "antigen loss," denoting different degrees of antigen reduction caused by different underlying mechanisms. Such mechanisms observed during CD19 CAR T-cell therapy include antigen downregulation, expression of different forms of the antigen lacking the target epitope (termed "antigen escape") and linage switch to a phenotypically distinct disease (173). As MM is characterized by high clonal competition, the promotion of antigen low/negative clones due to the selective pressure of the CAR T-cells appears a plausible mechanism of resistance. In fact, reduction of BCMA expression levels was reported during BCMA-directed CAR T-cell therapy (50) and development of relapse with both, BCMA positive and negative MM cells was described (44). One approach to mitigate antigen loss is to target more than one antigen.

\section{Multi-Antigen Specific CAR T-Cell Products}

Targeting more than one antigen can be achieved through multispecific CAR T-cell products containing two distinct Tcell populations of different specificities, one T-cell population with dual CAR expression, bicistronic CARs (where two independent CAR molecules are encoded on the same vector), or bivalent "tandem CARs" (recognizing two different antigens) (173), or CARs with three specificities using Designed Ankyrin Repeat Proteins (DARPins) (174). One example for tandem CARs is the APRIL-based CAR targeting both antigens, BCMA and TACI. This resulted in the prevention of a BCMA negative relapse in a preclinical in vivo model of MM, whereas CAR T-cells targeting solely BCMA did not (175). The APRIL-based CAR T-cell product is currently investigated in the AUTO2 trial (NCT03287804) (133). As mentioned previously, other multispecific CAR T-cell products containing a bicistronic BCMA and SLAMF7-directed CAR $(176,177)$ or simultaneously manufactured BCMA- and GPRC5D-directed CAR T-cells (121) have been investigated preclinically, and clinical testing of bispecific CAR T-cells targeting BCMA and CD38 (132) or BCMA and CD19 (178) are ongoing in China. Even if preliminary data of treatment with bispecific CAR T-cells has been encouraging, the comparison of bispecific and single-antigen specific CAR T-cells needs to be performed in randomized clinical trials (132). While targeting more than one antigen has the potential to increase CAR T-cell efficacy and reduce the risk of antigen loss, it increases the risk of on-target, off-tumor toxicities and the incorporation of respective safety measures is highly recommended.

\section{Modulation of Antigen Expression on Myeloma Cells}

Another strategy to reduce antigen loss is to improve maintenance of the antigen expression on MM cells. This can be achieved by pharmacological induction of increased surface antigen density, as demonstrated for the CD38-modulators all-trans retinoid acid (179), panobinostat (180), and ricolinostat (181). Furthermore, the identification of $\gamma$-secretase mediated cleavage of BCMA enabling the release of soluble BCMA has led to preclinical evaluation of the $\gamma$-secretase inhibitors RO4929097 and LY3039478 to increase BCMA expression on MM cells (182). Both agents conferred enhanced CAR T-cell reactivity to MM cells correlating with increased BCMA surface expression and reduced shedding of soluble BCMA. Interestingly, only three oral doses of LY3039478 increased the percentage of BCMA positive MM cells from below 30 to $99.3 \%$ in a small cohort of patients. These observations prompted the initiation of a clinical trial investigating the 
combination of BCMA CAR T-cells with pharmacological $\gamma$ secretase inhibition (183). First results are promising, especially as responses were observed in patients relapsing from previous BCMA-directed therapy.

\section{CAR T-CELL RELATED TOXICITIES}

The use of this novel therapy has brought in clinical practicein addition to the expected chemotherapy-related toxicitiesthe development of new specific and challenging side effects, including: CRS, neurological toxicity [also referred to as CAR-related encephalopathy syndrome (CRES)] also known as ICANS, on-target, off-tumor toxicity, anaphylaxis/allergy, insertional oncogenesis, tumor lysis syndrome, and delayed toxicities such as infections and prolonged cytopenia (184-186). An extensive review of CAR T-cell related toxicities is not the scope of this manuscript, as different publications have addressed this topic in detail $(77,184,185,187-189)$. Therefore, only a short overview will be provided.

CRS is the most frequent serious acute CAR T-cell related toxicity, with an absolute incidence of $30-100 \%$, and $10-30 \%$ for CRS grade $\geq 3$ (78). It is triggered by the activation and expansion of the CAR T-cells and lysis of normal and tumor cells, leading to the release of effector cytokines such as IL-2, tumor necrosis factor- $\alpha$ (TNF- $\alpha$ ) and interferon- $\gamma($ IFN- $\gamma)(190)$. Subsequently, the monocyte-macrophage system is activated and distinct pro-inflammatory cytokines such as IL-1, IL-6, IL10 , IFN- $\gamma$, monocyte chemoattractant protein-1 (MCP-1), and inducible nitric oxide synthase (iNOS) are released, leading to increased levels of C-reactive protein and ferritin (191-193). The clinical presentation can range from flu-like symptoms to life-threatening manifestations (hypotension, capillary leak, coagulopathy, and organ dysfunction). The management of CRS requires a proper severity grading $(185,186,194,195)$. The treatment of CRS is based on supportive care with antipyretics, IV hydration, vasopressor support, supplemental oxygen and, in severe cases, the use of the specific IL6 receptor antagonist tocilizumab and corticosteroids (185, 189, 194, 196, 197). Another potential, but currently still experimental procedure to prevent CRS could be the use of dasatinib that acts as a pharmacologic on/off switch for CAR T-cells (198).

ICANS is the second most frequent adverse event after CAR T-cell infusion, with an incidence of $0-87 \%(2-4,187)$. The pathophysiology is not completely understood; nevertheless, there is evidence pointing toward an impairment of the blood brain barrier due to increased levels of TNF- $\alpha$, IL-6, IL-1, IFN$\gamma$, IL-10, IL-8, MCP-1, quinolinic acid, and glutamate (199201). ICANS can develop concurrently with or without CRS (199). Symptoms are variable, ranging from toxic encephalopathy with word-finding difficulty, aphasia, and confusion to more severe cases with coma, seizures and cerebral edema (185, $186,189)$. The treatment is based on supportive care and corticosteroids are reserved for grade 3 or 4 ICANS. The use of tocilizumab is recommended only if there is concurrent CRS $(185,188,189,199,202)$.
Regarding on-target, off-tumor toxicity, the typical example is the development of B-cell aplasia and hypogammaglobulinemia following treatment with CD19 CAR T-cells $(185,188,189)$. Further examples of on-target, off-tumor toxicity include carboxyanhydrase-IX-specific CAR T-cell therapy for renal cell carcinoma that resulted in the development of cholestasis due to expression of this antigen on bile duct epithelium (203), and unfortunately, the infusion of HER-2/neu CAR T-cells in a patient with advanced colonic cancer that led to respiratory distress and cardiac arrest which was attributed to putative low levels of HER-2/neu expression on lung epithelial cells (204).

Another theoretical danger with the use of genetically modified cell products is the possibility of insertional oncogenesis; nevertheless, no cases have been reported so far $(205,206)$. However, in the case of a patient with chronic lymphocytic leukemia receiving CD19 CAR T-cells, a clonal expansion of a single CAR T-cell with biallelic TET2 dysfunction was reported (207). Therefore, strict long-term monitoring of patients receiving CAR T-cell therapy should be implemented.

\section{CLINICAL AND LOGISTICAL CHALLENGES OF INCORPORATING CAR T-CELLS INTO THE CURRENT TREATMENT LANDSCAPE IN MM}

The optimal timing of CAR T-cell therapy in the sequence of anti-myeloma therapy is still an open question. The most urgent unmet clinical need remains in patient subgroups with extensive pretreatment history who are often multi-agent refractory and suffer from highly aggressive disease. However, it is postulated that CAR T-cell products generated in the RR setting display inferior clinical efficacy than products generated from patients after first-line induction therapy (167). In fact, a recent metaanalysis of 15 clinical trials (thereof 14 in RRMM, only 1 in NDMM) documented a CR rate of $36 \%$ with MRD negativity in 77\% (208) and a mPFS of 10 months. Therefore, the curative potential in the respective patient cohorts is limited to date. The implementation of a CAR T-cell therapy as early intervention appears more promising, particularly since it is designed as a single dose therapy. However, the last decade has brought in place a variety of highly effective anti-MM drugs that are increasingly moving to frontline therapy and improve survival (209-211). Therefore, deliberate study designs and long followup periods will be required for head-to-head comparisons of single dose CAR T-cell treatment and continuous "conventional" anti-myeloma therapy.

However, such data will be essential for the fate of CAR T-cell therapy in $\mathrm{MM}$, especially when socioeconomic considerations are taken into account. The generation of autologous CAR $\mathrm{T}$-cell products is a time consuming, labor- and resourceintensive procedure and special prerequisites are required for transportation, storage and administration. In this regard, efforts to generate "off-the-shelf" CAR T-cells as well as standardized logistics at certified medical facilities are essential developments. However, for broad application of CAR T-cells, a favorable costeffectiveness ratio will be required. Treatment costs are expected 
on a similar level as the FDA/EMA approved anti-CD19 CAR T-cell products $\left(\$ 475.000\right.$, Kymriah ${ }^{\circledR} ; \$ 373.000$, Yescarta $\left.{ }^{\circledR}\right)$. For both products, the Institute for Clinical and Economic Research (ICER) estimated a cost-effectiveness below \$150.000 per quality-adjusted life-year (QALY) gained (212), a threshold that is commonly considered cost effective. However, the longterm effectiveness is the critical, yet unknown determinant of a product's cost-effectiveness (213). Therefore, incorporation into a curative strategy will be decisive for CAR T-cells as anti-myeloma treatment in the future.

\section{CONCLUSIONS}

The treatment arsenal in MM has grown considerably during the last decade and idecabtagene vicleucel and other CAR T-cell products are on their way to approval. However, the clinical value of CAR T-cells in the current landscape of myeloma therapies remains to be determined. Besides the various advanced $\mathrm{T}$ cell engineering strategies, clinical, and economic factors will have to be taken into account for successful incorporation of CAR T-cells into existing treatment paradigms. Optimal patient selection will be crucial, not only with regards to timing in the course of the disease, but also concerning disease-specific factors like extramedullary manifestations or cytogenetic highrisk features. Also, feasibility of the manufacturing in terms of production capacities and time interval from leukapheresis to adoptive transfer will impact whether CAR T-cells take root into

\section{REFERENCES}

1. Kumar SK, Rajkumar V, Kyle RA, van Duin M, Sonneveld P, Mateos M-V, et al. Multiple myeloma. Nat Rev Dis Primer. (2017) 3:17046. doi: 10.1038/nrdp.2017.46

2. Maude SL, Laetsch TW, Buechner J, Rives S, Boyer M, Bittencourt H, et al. Tisagenlecleucel in children and young adults with B-cell lymphoblastic leukemia. N Engl J Med. (2018) 378:439-448. doi: 10.1056/NEJMoa1709866

3. Schuster SJ, Svoboda J, Chong EA, Nasta SD, Mato AR, Anak Ö, et al. Chimeric antigen receptor T cells in refractory B-cell lymphomas. N Engl J Med. (2017) 377:2545-54. doi: 10.1056/NEJMoa1708566

4. Neelapu SS, Locke FL, Bartlett NL, Lekakis LJ, Miklos DB, Jacobson CA, et al. Axicabtagene ciloleucel CAR T-cell therapy in refractory large Bcell lymphoma. N Engl J Med. (2017) 377:2531-44. doi: 10.1056/NEJMoa17 07447

5. Kuwana Y, Asakura Y, Utsunomiya N, Nakanishi M, Arata Y, Itoh S, et al. Expression of chimeric receptor composed of immunoglobulin-derived $\mathrm{v}$ regions and T-cell receptor-derived c regions. Biochem Biophys Res Commun. (1987) 149:960-8. doi: 10.1016/0006-291x (87) 90502-x

6. Eshhar Z, Waks T, Gross G, Schindler DG. Specific activation and targeting of cytotoxic lymphocytes through chimeric single chains consisting of antibody-binding domains and the gamma or zeta subunits of the immunoglobulin and T-cell receptors. Proc Natl Acad Sci USA. (1993) 90:720-4. doi: 10.1073/pnas.90.2.720

7. Peinert S, Prince HM, Guru PM, Kershaw MH, Smyth MJ, Trapani JA, et al. Gene-modified T cells as immunotherapy for multiple myeloma and acute myeloid leukemia expressing the lewis Y antigen. Gene Ther. (2010) 17:678-86. doi: 10.1038/gt.2010.21

8. Garfall AL, Maus MV, Hwang W-T, Lacey SF, Mahnke YD, Melenhorst J, et al. Chimeric antigen receptor T cells against CD19 for multiple myeloma. N Engl J Med. (2015) 373:1040-7. doi: 10.1056/NEJMoa1504542 clinical routine. And although no such cell product is currently commercially available for the treatment of MM, treatment costs are expected on a comparable scale as the approved CD19 CAR T-cell products. Eventually, more robust long-term data and, ideally, evidence of curative potential will shape the future of CAR T-cells in this disease. Therefore, clinicians, researchers and society need to collaborate to maximize patients' benefit.

\section{AUTHOR CONTRIBUTIONS}

LR-L, MG, and SD wrote and reviewed the manuscript. CF, MH, and HE reviewed the manuscript. All authors approved the final version of the manuscript.

\section{FUNDING}

This work has been supported in part by grants from the Instituto de Salud Carlos III, Spanish Ministry of Health (FIS PI19/00669), Fondo Europeo de Desarrollo Regional (FEDER), and 2017SGR00792 (AGAUR; Generalitat de Catalunya).

\section{ACKNOWLEDGMENTS}

LR-L as BITRECS fellow has received funding from the European Union's Horizon 2020 research and innovation programme under the Marie Sklodowska-Curie grant agreement no. 754550 and from La Caixa Foundation.
9. Guo B, Chen M, Han Q, Hui F, Dai H, Zhang W, et al. CD138directed adoptive immunotherapy of chimeric antigen receptor (CAR) modified T cells for multiple myeloma. J Cell Immunother. (2016) 2:2835. doi: 10.1016/j.jocit.2014.11.001

10. Ramos CA, Savoldo B, Torrano V, Ballard B, Zhang H, Dakhova O-F, et al. Clinical responses with $\mathrm{T}$ lymphocytes targeting malignancy-associated $\kappa$ light chains. J Clin Invest. (2016) 126:2588-96. doi: 10.1172/JCI86000

11. Schubert M-L, Hoffmann J-M, Dreger P, Müller-Tidow C, Schmitt M. Chimeric Antigen receptor transduced $t$ cells: tuning up for the next generation. Int J Cancer. (2018) 142:1738-47. doi: 10.1002/ijc.31147

12. Garrido F, Aptsiauri N, Doorduijn EM, Garcia Lora AM, van Hall T. The Urgent need to recover MHC class i in cancers for effective immunotherapy. Curr Opin Immunol. (2016) 39:44-51. doi: 10.1016/j.coi.2015.12.007

13. Schuberth PC, Jakka G, Jensen SM, Wadle A, Gautschi F, Haley D, et al. Effector memory and central memory NY-ESO-1-specific re-directed T cells for treatment of multiple myeloma. Gene Ther. (2013) 20:38695. doi: 10.1038/gt.2012.48

14. Johnson LA, Morgan RA, Dudley ME, Cassard L, Yang JC, Hughes MS, et al., Gene therapy with human and mouse T-cell receptors mediates cancer regression and targets normal tissues expressing cognate antigen. Blood. (2009) 114:535-46. doi: 10.1182/blood-2009-03-211714

15. Madry C, Laabi Y, Callebaut I, Roussel J, Hatzoglou A, Le Coniat M, et al. The characterization of murine BCMA gene defines it as a new member of the tumor necrosis factor receptor superfamily. Int Immunol. (1998) 10:1693-702. doi: 10.1093/intimm/10.11.1693

16. Ng LG, Mackay CR, Mackay F. The BAFF/APRIL system: life beyond B lymphocytes. Mol Immunol. (2005) 42:76372. doi: 10.1016/j.molimm.2004.06.041

17. Mackay F, Tangye SG. The role of the BAFF/APRIL system in B cell homeostasis and lymphoid cancers. Curr Opin Pharmacol. (2004) 4:34754. doi: 10.1016/j.coph.2004.02.009 
18. Avery DT, Kalled SL, Ellyard JI, Ambrose C, Bixler SA, Thien MG, et al. BAFF selectively enhances the survival of plasmablasts generated from human memory B cells. J Clin Invest. (2003) 112:286-97. doi: 10.1172/JCI18025

19. O'Connor BP, Raman VS, Erickson LD, Cook WJ, Weaver LK, Ahonen C-L, et al. BCMA is essential for the survival of long-lived bone marrow plasma cells. J Exp Med. (2004) 199:91-8. doi: 10.1084/jem.20031330

20. Rickert RC, Jellusova J, Miletic AV. Signaling by the tumor necrosis factor receptor superfamily in B-cell biology and disease. Immunol Rev. (2011) 244:115-33. doi: 10.1111/j.1600-065X.2011.01067.x

21. Carpenter RO, Evbuomwan MO, Pittaluga S, Rose JJ, Raffeld M, Yang $\mathrm{S}$, et al. B-cell maturation antigen is a promising target for adoptive T-cell therapy of multiple myeloma. Clin Cancer Res. (2013) 19:204860. doi: 10.1158/1078-0432.CCR-12-2422

22. Tai Y-T, Mayes PA, Acharya C, Zhong MY, Cea M, Cagnetta A, et al. Novel anti-B-cell maturation antigen antibody-drug conjugate (GSK2857916) selectively induces killing of multiple myeloma. Blood. (2014) 123:312838. doi: 10.1182/blood-2013-10-535088

23. Mackay F, Schneider P, Rennert P, Browning, J. BAFF and APRIL: a tutorial on B cell survival. Annu Rev Immunol. (2003) 21:23164. doi: 10.1146/annurev.immunol.21.120601.141152

24. Benson MJ, Dillon SR, Castigli E, Geha RS, Xu S, Lam-P, et al. Cutting edge: the dependence of plasma cells and independence of memory B cells on BAFF and april. J Immunol. Baltim. Md. (2008) 180:36559. doi: 10.4049/jimmunol.180.6.3655

25. Belnoue E, Pihlgren M, McGaha TL, Tougne C, Rochat A-F, Bossen C-H, et al. APRIL is critical for plasmablast survival in the bone marrow and poorly expressed by early-life bone marrow stromal cells. Blood. (2008) 111:2755-64. doi: 10.1182/blood-2007-09-110858

26. $\mathrm{Xu} \mathrm{S}$, Lam KP. B-cell maturation protein, which binds the tumor necrosis factor family members BAFF and APRIL, is dispensable for humoral immune responses. Mol Cell Biol. (2001) 21:4067-74. doi: 10.1128/MCB.21.12.4067-4074.2001

27. Moreaux J, Legouffe E, Jourdan E, Quittet P, Rème T, Lugagne CK, et al. BAFF and APRIL protect myeloma cells from apoptosis induced by interleukin 6 deprivation and dexamethasone. Blood. (2004) 103:314857. doi: 10.1182/blood-2003-06-1984

28. Novak AJ, Darce JR, Arendt BK, Harder B, Henderson K, Kindsvogel $\mathrm{W}$, et al. Expression of BCMA, TACI, and BAFF-R in multiple myeloma: a mechanism for growth and survival. Blood. (2004) 103:68994. doi: 10.1182/blood-2003-06-2043

29. Moreaux J, Cremer FW, Reme T, Raab M, Mahtouk K, Kaukel P, et al. The level of TACI gene expression in myeloma cells is associated with a signature of microenvironment dependence versus A plasmablastic signature. Blood. (2005) 106:1021-30. doi: 10.1182/blood-2004-11-4512

30. Tai YT, Li XF, Breitkreutz I, Song W, Neri P, Catley L, et al. Role of Bcell-activating factor in adhesion and growth of human multiple myeloma cells in the bone marrow microenvironment. Cancer Res. (2006) 66:667582. doi: 10.1158/0008-5472.CAN-06-0190

31. Moreaux J, Sprynski A-C, Dillon SR, Mahtouk K, Jourdan M, Ythier A, et al. APRIL, and TACI Interact with syndecan-1 on the surface of multiple myeloma cells to form an essential survival loop. Eur J Haematol. (2009) 83:119-29. doi: 10.1111/j.1600-0609.2009.01262.x

32. Neri P, Kumar S, Fulciniti MT, Vallet S, Chhetri S, Mukherjee S, et al. Neutralizing B-cell activating factor antibody improves survival and inhibits osteoclastogenesis in a severe combined immunodeficient human multiple myeloma model. Clin Cancer Res. (2007) 13:59039. doi: 10.1158/1078-0432.CCR-07-0753

33. Frigyesi I, Adolfsson J, Ali M, Christophersen MK, Johnsson E, Turesson I, et al. Robust isolation of malignant plasma cells in multiple myeloma. Blood. (2014) 123:1336-40. doi: 10.1182/blood-2013-09529800

34. Tarte K, De Vos J, Thykjaer T, Zhan F, Fiol G, Costes V, et al. Generation of polyclonal plasmablasts from peripheral blood B cells: a normal counterpart of malignant plasmablasts. Blood. (2002) 100:1113-22. doi: 10.1182/blood.V100.4.1113.h81602001113_1113_1122

35. Claudio JO, Masih-Khan E, Tang H, Gonçalves J, Voralia M, Li ZH, et al. A molecular compendium of genes expressed in multiple myeloma. Blood. (2002) 100:2175-86. doi: 10.1182/blood-2002-01-0008
36. Tai, Y-T, Acharya C, An G, Moschetta M, Zhong MY, Feng X, et al. APRIL and BCMA promote human multiple myeloma growth and immunosuppression in the bone marrow microenvironment. Blood. (2016) 127:3225-36. doi: 10.1182/blood-2016-01-691162

37. Bellucci R, Wu CJ, Chiaretti S, Weller E, Davies FE, Alyea EP, et al. Complete response to donor lymphocyte infusion in multiple myeloma is associated with antibody responses to highly expressed antigens. Blood. (2004) 103:65663. doi: 10.1182/blood-2003-07-2559

38. Laurent SA, Hoffmann FS, Kuhn, P-H Cheng Q, Chu Y, Schmidt-Supprian $\mathrm{M}$, et al. Secretase directly sheds the survival receptor BCMA from plasma cells. Nat Commun. (2015) 6:7333. doi: 10.1038/ncomms8333

39. Sanchez E, Gillespie A, Tang G, Ferros M, Harutyunyan NM, Vardanyan $\mathrm{S}$, et al. Soluble B-cell maturation antigen mediates tumor-induced immune deficiency in multiple myeloma. Clin. Cancer Res. (2016) 22:338397. doi: 10.1158/1078-0432.CCR-15-2224

40. Sanchez E, Li M, Kitto A, Li J, Wang CS, Kirk DT, et al. Serum Bcell maturation antigen is elevated in multiple myeloma and correlates with disease status and survival. Br J Haematol. (2012) 158:72738. doi: 10.1111/j.1365-2141.2012.09241.x

41. Ghermezi M, Li M, Vardanyan S, Harutyunyan NM, Gottlieb J, Berenson A, et al. Serum B-cell maturation antigen: a novel biomarker to predict outcomes for multiple myeloma patients. Haematologica. (2017) 102:78595. doi: 10.3324/haematol.2016.150896

42. Bujarski S, Soof C, Chen H, Li M, Sanchez E, Wang CS, et al. Serum B-cell maturation antigen levels to predict progression free survival and responses among relapsed or refractory multiple myeloma patients treated on the phase i IRUX trial. J Clin Oncol. (2018) 36 (15 Suppl.):e24313. doi: 10.1200/JCO.2018.36.15/suppl.e24313

43. Chen $\mathrm{H}, \mathrm{Li} \mathrm{M}, \mathrm{Xu} \mathrm{N}, \mathrm{Ng} \mathrm{N}$, Sanchez E, Soof CM, et al. Serum B-cell maturation antigen (BCMA) reduces binding of ANTIBCMA antibody to multiple myeloma cells. Leuk Res. (2019) 81:62-6. doi: 10.1016/j.leukres.2019.04.008

44. Brudno JN, Maric I, Hartman SD, Rose JJ, Wang M, Lam N, et al. T cells genetically modified to express an anti-B-cell maturation antigen chimeric antigen receptor cause remissions of poor-prognosis relapsed multiple myeloma. J Clin Oncol. (2018) 36:2267-80. doi: 10.1200/JCO.2018.77.8084

45. Zhao W-H, Liu J, Wang B-Y, Cao X-M, Yang Y, Zhang Y, et al. A phase 1, open-label study of LCAR-B38M, a chimeric antigen receptor $\mathrm{T}$ cell therapy directed against $\mathrm{B}$ cell maturation antigen, in patients with relapsed or refractory multiple myeloma. J Hematol Oncol. (2018) 11:141. doi: 10.1186/s13045-018-0681-6

46. Wang, B-Y, Zhao W-H, Liu J, Chen Y-X, Cao X-M, Yang Y, et al. Longterm follow-up of a phase 1, first-in-human open-label study of LCAR$\mathrm{B} 38 \mathrm{M}$, a structurally differentiated chimeric antigen receptor $\mathrm{T}$ (CART) Cell therapy targeting B-cell maturation antigen (BCMA), in patients (Pts) with relapsed/refractory multiple myeloma (RRMM) Blood. (2019) 134(Suppl_1):579.doi: 10.1182/blood-2019-124953

47. Xu J, Chen LJ, Yang SS, Sun Y, Wu W, Liu YF, et al. Exploratory trial of a biepitopic CAR T-targeting B cell maturation antigen in relapsed/refractory multiple myeloma. Proc Natl Acad Sci USA. (2019) 116:9543-51. doi: 10.1073/pnas.1819745116

48. Madduri D, Usmani SZ, Jagannath S, Singh I, Zudaire E, Yeh T-M, et al. Results from CARTITUDE-1: A phase 1b/2 study of JNJ-4528, a CAR-T cell therapy directed against B-cell maturation antigen (BCMA), in patients with relapsed and/or refractory multiple myeloma (R/R MM) Blood. (2019) 134(Suppl_ 1):577. doi: 10.1182/blood-2019-121731

49. Berdeja JG, Madduri D, Usmani SZ, Singh I, Zudaire E, Allred AJ, et al. Update of cartitude-1: A phase Ib/II study of JNJ-4528, a B-cell maturation antigen (BCMA) -directed CAR-T-cell therapy, in relapsed/refractory multiple myeloma. J Clin Oncol. (2020) 38 (15_Suppl.):8505. doi: 10.1200/JCO.2020.38.15/suppl.8505

50. Cohen AD, Garfall AL, Stadtmauer EA, Melenhorst JJ, Lacey SF, Lancaster $\mathrm{E}$, et al. B cell maturation antigen-specific CAR T cells are clinically active in multiple myeloma. J Clin Invest. (2019) 129:2210-21. doi: 10.1172/JCI1 26397

51. Raje N, Berdeja J, Lin Y, Siegel D, Jagannath S, Madduri D-P, et al. AntiBCMA CAR T-cell therapy Bb2121 in relapsed or refractory multiple myeloma. N Engl J Med. (2019) 380:1726-37. doi: 10.1056/NEJMoa1817226 
52. Bristol-Myers Squibb and BlueBird Bio Announce Positive Top-line Results from the Pivotal Phase 2 Kar MMa Study of Ide-cel in Relapsed and Refractory Multiple Myeloma | BMS Newsroom. (2019). Available online at: https://news.bms.com/press-release/corporatefinancial-news/bristolmyers-squibb-and-bluebird-bio-announce-positive-top-li (accessed March 6, 2020).

53. Munshi NC, Anderson J, Larry D, Shah N, Jagannath S, Berdeja JG, et al. Idecabtagene vicleucel (Ide-Cel; Bb2121), a BCMA-targeted CAR Tcell therapy, in patients with relapsed and refractory multiple myeloma (RRMM): initial Kar MMa results. J Clin Oncol. (2020) 38 (15_Suppl):8503. doi: 10.1200/JCO.2020.38.15/suppl.8503

54. Berdeja JG, Alsina M, Shah ND, Siegel DS, Jagannath S, Madduri $D$, et al. Updated results from an ongoing phase 1 clinical study of Bb21217 anti-bcma CAR T cell therapy. Blood. (2019) 134(Suppl_ 1):927. doi: 10.1182/blood-2019-126660

55. Mailankody S, Htut M, Lee KP, Bensinger W, Devries T, Piasecki $\mathrm{J}$, et al. JCARH125 A, anti-BCMA CAR T-cell therapy for relapsed/refractory multiple myeloma: initial proof of concept results from a Phase 1/2 multicenter study (EVOLVE) Blood. (2018) 132(Suppl_1):957. doi: 10.1182/blood-2018-99-113548

56. Mailankody S, Jakubowiak AJ, Htut M, Costa LJ, Lee K, Ganguly $\mathrm{S}$, et al. Orvacabtagene autoleucel (Orva-Cel), a B-cell maturation antigen (BCMA) -directed CAR T cell therapy for patients (Pts) with relapsed/refractory multiple myeloma (RRMM): update of the phase $1 / 2$ EVOLVE study (NCT03430011) J Clin Oncol. (2020) 38 (15_Suppl.):8504. doi: 10.1200/JCO.2020.38.15/suppl.8504

57. Mailankody S, Ghosh A, Staehr M, Purdon TJ, Roshal M, Halton E, et al. Clinical responses and pharmacokinetics of MCARH171, a human-derived $\mathrm{Bcma}$ targeted CAR $\mathrm{T}$ cell therapy in relapsed/refractory multiple myeloma: final results of a phase i clinical trial. Blood. (2018) 132(Supplement 1):959. doi: 10.1182/blood-2018-99-119717

58. Green DJ, Pont M, Sather BD, Cowan AJ, Turtle CJ, Till BG, et al. Fully human $\mathrm{Bcma}$ targeted chimeric antigen receptor $\mathrm{T}$ cells administered in a defined composition demonstrate potency at low doses in advanced stage high risk multiple myeloma. Blood. (2018) 132(Supplement 1):10111. doi: 10.1182/blood-2018-99-117729

59. Gregory T, Cohen AD, Costello CL, Ali SA, Berdeja JG, Ostertag EM, et al. Efficacy and safety of P-Bcma-101 CAR-T cells in patients with relapsed/refractory ( $\mathrm{r} / \mathrm{r}$ ) multiple myeloma (MM) Blood. (2018) 132(Suppl_1):1012. doi: 10.1182/blood-2018-99-111419

60. Costello CL, Gregory TK, Ali SA, Berdeja JG, Patel KK, Shah ND, et al. Phase 2 study of the response and safety of P-Bcma-101 CAR-T cells in patients with relapsed/refractory ( $\mathrm{r} / \mathrm{r}$ ) multiple myeloma (MM) (PRIME) Blood. (2019) 134(Suppl_1):3184. doi: 10.1182/blood-2019-129562

61. Li C, Wang Q, Zhu H, Mao X, Wang Y, Zhang Y, et al. T cells expressing anti B-cell maturation antigen chimeric antigen receptors for plasma cell malignancies. Blood. (2018) 132(Supplement 1):1013. doi: 10.1182/blood-2018-99-116898

62. Jie J, Hao S, Jiang S, Li Z, Yang M, Zhang W, et al. Phase 1 trial of the safety and efficacy of fully human anti-Bcma CAR $T$ cells in relapsed/refractory multiple myeloma. Blood. (2019) 134(Supplement 1):4435. doi: 10.1182/blood-2019-126104

63. Li C, Wang J, Wang D, Hu G, Yang Y, Zhou X, et al. Efficacy and safety of fully human Bcma targeting CAR $T$ cell therapy in relapsed/refractory multiple myeloma. Blood. (2019) 134(Supplement 1):929. doi: 10.1182/blood-2019-128468

64. Mikkilineni L, Manasanch EE, Lam N, Vanasse D, Brudno JN, Maric IW, et al. T cells expressing an anti-B-cell maturation antigen (BCMA) chimeric antigen receptor with a fully-human heavy-chain-only antigen recognition domain induce remissions in patients with relapsed multiple myeloma. Blood. (2019) 134(Suppl_1):3230. doi: 10.1182/blood-2019129088

65. Lam N, Trinklein ND, Buelow B, Patterson GH, Ojha N, Kochenderfer JN. Anti-BCMA chimeric antigen receptors with fully human heavychain-only antigen recognition domains. Nat. Commun. (2020) 11:283. doi: 10.1038/s41467-019-14119-9

66. Liu Y, Chen Z, Fang H, Wei R, Yu K, Jiang $S$, et al. Durable remission achieved from $\mathrm{Bcma-Directed} \mathrm{CAR-T} \mathrm{therapy} \mathrm{against}$ relapsed or refractory multiple myeloma. Blood. (2018) 132(Suppl. 1):956. doi: 10.1182/blood-2018-99-112786

67. Ali SA, Shi V, Maric I, Wang M, Stroncek DF, Rose JJ, et al. $\mathrm{T}$ cells expressing an anti-B-cell maturation antigen chimeric antigen receptor cause remissions of multiple myeloma. Blood. (2016) 128:1688700. doi: 10.1182/blood-2016-04-711903

68. Zudaire E, Madduri D, Usmani SZ, Jakubowiak A, Berdeja JG, Geng D, et al. Translational analysis from CARTITUDE-1, an ongoing phase $1 \mathrm{~b} / 2$ study of JNJ-4528 BCMA-targeted CAR-T cell therapy in relapsed and/or refractory multiple myeloma (R/R MM), indicates preferential expansion of CD8+ T cell central memory cell subset. Blood. (2019) 134(Supplement 1):928. doi: 10.1182/blood-2019-127309

69. Bu DX, Singh R, Choi EE, Ruella M, Nunez-Cruz S, Mansfield KG, et al. Pre-clinical validation of B cell maturation antigen (BCMA) as a target for $\mathrm{T}$ cell immunotherapy of multiple myeloma. Oncotarget. (2018) 9:2576480. doi: 10.18632/oncotarget. 25359

70. Friedman KM, Garrett TE, Evans JW, Horton HM, Latimer HJ, Seidel $\mathrm{SL}$, et al. Effective targeting of multiple B-cell maturation antigenexpressing hematological malignances by anti-B-cell maturation antigen chimeric antigen receptor T cells. Hum. Gene Ther. (2018) 29:585601. doi: 10.1089/hum.2018.001

71. Efficacy and Safety Study of bb2121 Versus Standard Triplet Regimens in Subjects With Relapsed and Refractory Multiple Myeloma (RRMM). (2018). Available online at: https://clinicaltrials.gov/ct2/show/NCT03651128 (accessed January 19, 2020).

72. An Efficacy and Safety Study of bb2121 in Subjects With Relapsed and Refractory Multiple Myeloma and in Subjects With High-Risk Multiple Myeloma. (2020). Available online at: https:/clinicaltrials.gov/ct2/show/ NCT03601078 (accessed January 19, 2020).

73. A Study to Evaluate the Safety of bb2121 in Subjects With High Risk, Newly Diagnosed Multiple Myeloma (NDMM) (Kar MMa-4). (2019). Available online at: https://clinicaltrials.gov/ct2/show/NCT04196491 (accessed January 19, 2020).

74. Fraietta JA, Lacey SF, Orlando EJ, Pruteanu-Malinici I, Gohil M, Lundh S, et al. Determinants of response and resistance to CD19 chimeric antigen receptor (CAR) T cell therapy of chronic lymphocytic leukemia. Nat Med. (2018) 24:563-71. doi: 10.1038/s41591-0180010-1

75. Klebanoff CA, Crompton JG, Leonardi AJ, Yamamoto TN, Chandran SS, Eil $\mathrm{RL}$, et al. Inhibition of AKT signaling uncouples $\mathrm{T}$ cell differentiation from expansion for receptor-engineered adoptive immunotherapy. JCI Insight. (2017) 2:e95103. doi: 10.1172/jci.insight.95103

76. Smith EL, Staehr M, Masakayan R, Tatake IJ, Purdon TJ, Wang X, et al. Development and evaluation of an optimal human single-chain variable fragment-derived BCMA-targeted CAR T cell vector. Mol Ther J Am Soc Gene Ther. (2018) 26:1447-56. doi: 10.1016/j.ymthe.2018.03.016

77. Brudno JN, Kochenderfer JN. Recent advances in CAR T-cell toxicity: mechanisms, manifestations and management. Blood Rev. (2019) 34:4555. doi: 10.1016/j.blre.2018.11.002

78. Frey N, Porter D. Cytokine release syndrome with chimeric antigen receptor T cell therapy. Biol Blood Marrow Transplant. (2019) 25:e123e7. doi: 10.1016/j.bbmt.2018.12.756

79. Garfall AL, Stadtmauer EA, Hwang WT, Lacey SF, Melenhorst JJ, Krevvata M, et al. Anti-CD19 CAR T cells with high-dose melphalan and autologous stem cell transplantation for refractory multiple myeloma. JCI Insight. (2019) 4:e127684. doi: 10.1172/jci.insight.127684

80. Nerreter T, Letschert S, Götz R, Doose S, Danhof S, Einsele H, et al. Superresolution microscopy reveals ultra-low CD19 expression on myeloma cells that triggers elimination by CD19 CAR-T. Nat. Commun. (2019) 10:3137. doi: 10.1038/s41467-019-10948-w

81. Matsui W, Wang Q, Barber JP, Brennan S, Smith BD, Borrello I, et al. Clonogenic multiple myeloma progenitors, stem cell properties, drug resistance. Cancer Res. (2008) 68:1907. doi: 10.1158/0008-5472.CAN-07-3096

82. Paiva B, Puig N, Cedena MT, de Jong BG, Ruiz Y, Rapado I$B$, et al. Differentiation stage of myeloma plasma cells: biological and clinical significance. Leukemia. (2017) 31:382-92. doi: 10.1038/leu. 2016.211 
83. Yan Z, Cao J, Cheng H, Qiao J, Zhang H, Wang Y, et al. A combination of humanised anti-CD19 and anti-BCMA CAR T cells in patients with relapsed or refractory multiple myeloma: a single-arm, phase 2 trial. Lancet Haematol. (2019) 6:e521-e9. doi: 10.1016/S2352-3026 (19) 30115-2

84. Shi X, Yan L, Shang J, Qu S, Kang L, Zhou J, et al. Tandom autologous transplantation and combined infusion of CD19 and Bcmaspecific chimeric antigen receptor $\mathrm{T}$ cells for high risk MM: initial safety and efficacy report from a clinical pilot study. Blood. (2018) 132(Suppl. 1):1009. doi: 10.1182/blood-2018-99-117964

85. Hsi ED, Steinle R, Balasa B, Szmania S, Draksharapu A, Shum $\mathrm{BP}$, et al. CS1 a potential new therapeutic antibody target for the treatment of multiple myeloma. Clin Cancer Res. (2008) 14:277584. doi: 10.1158/1078-0432.CCR-07-4246

86. Tai YT, Dillon M, Song W, Leiba M, Li XF, Burger P, et al. Anti-CS1 humanized monoclonal antibody huluc63 inhibits myeloma cell adhesion and induces antibody-dependent cellular cytotoxicity in the bone marrow milieu. Blood. (2008) 112:1329-37. doi: 10.1182/blood-2007-08-107292

87. De Salort J, Sintes J, Llinàs L, Matesanz-Isabel J, Engel $P$. Expression of SLAM (CD150) cell-surface receptors on human B-cell subsets: from pro-B to plasma cells. Immunol Lett. (2011) 134:129-36. doi: 10.1016/j.imlet.2010.09.021

88. Campbell KS, Cohen AD, Pazina T. Mechanisms of NK cell activation and clinical activity of the therapeutic SLAMF7 antibody, elotuzumab in multiple myeloma. Front Immunol. (2018) 9:2551. doi: 10.3389/fimmu.2018.02551

89. Veillette, A. SLAM-family receptors: immune regulators with or without SAP-family adaptors. Cold Spring Harb Perspect Biol. (2010) 2:a002469. doi: 10.1101/cshperspect.a002469

90. Chen J, Zhong MC, Guo H, Davidson D, Mishel S, Lu Y, et al. SLAMF7 is critical for phagocytosis of haematopoietic tumour cells via Mac-1 integrin. Nature. (2017) 544:493-497. doi: 10.1038/nature22076

91. Lonial S, Dimopoulos M, Palumbo A, White D, Grosicki S, Spicka I, et al. Elotuzumab therapy for relapsed or refractory multiple myeloma. $\mathrm{N} \mathrm{Engl} \mathrm{J}$ Med. (2015) 373:621-31. doi: 10.1056/NEJMoa1505654

92. Gogishvili T, Danhof S, Prommersberger S, Rydzek J, Schreder M, Brede $\mathrm{C}$, et al. SLAMF7-CAR T cells eliminate myeloma and confer selective fratricide of SLAMF7+ normal lymphocytes. Blood. (2017) 130:283847. doi: 10.1182/blood-2017-04-778423

93. Monjezi R, Miskey C, Gogishvili T, Schleef M, Schmeer M, Einsele $\mathrm{H}$, et al. Enhanced CAR T-cell engineering using non-viral sleeping beauty transposition from minicircle vectors. Leukemia. (2017) 31:18694. doi: 10.1038/leu.2016.180

94. Miskey C, Amberger M, Reiser M, Prommersberger S, Beckmann J, Machwirth $M$, et al. Genomic analyses of SLAMF7 CAR-T cells manufactured by sleeping beauty transposon gene transfer for immunotherapy of multiple myeloma. bioRxiv. (2019) 675009. doi: 10.1101/675009

95. Mathur R, Zhang Z, He J, Galetto R, Gouble A, Chion-Sotinel I, et al. Universal SLAMF7-Specific CAR T-cells as treatment for multiple myeloma. Blood. (2017) 130(Suppl. 1):502. doi: 10.1182/blood.V130.Suppl/1. 502.502

96. Liebisch P, Eppinger S, Schöpflin C, Stehle G, Munzert G, Döhner H, et al. CD44v6, a target for novel antibody treatment approaches, is frequently expressed in multiple myeloma and associated with deletion of chromosome arm 13q. Haematologica. (2005) 90:489-93.

97. Casucci M, Falcone L, Camisa B, Norelli M, Porcellini S, Stornaiuolo A, et al. Extracellular NGFR spacers allow efficient tracking and enrichment of fully functional CAR-T cells co-expressing a suicide gene. Front Immunol. (2018) 9:507. doi: 10.3389/fimmu.2018.00507

98. Norelli M, Camisa B, Barbiera G, Falcone L, Purevdorj A, Genua M, et al. Monocyte-derived IL-1 and IL-6 are differentially required for cytokinerelease syndrome and neurotoxicity due to CAR T Cells. Nat Med. (2018) 24:739-48. doi: 10.1038/s41591-018-0036-4

99. Tijink BM, Buter J, de Bree R, Giaccone G, Lang MS, Staab A, et al. A phase I dose escalation study with anti-CD44v6 bivatuzumab mertansine in patients with incurable squamous cell carcinoma of the head and neck or esophagus. Clin Cancer Res. (2006) 12:6064-72. doi: 10.1158/1078-0432.CCR06-0910
100. Carrabba MG, Casucci M, Hudecek M, Quintarelli C, Briones J, Hajek R, et al. Phase I-IIa clinical trial to assess safety and efficacy of MLM-CAR44.1, a CD44v6 Directed CAR-T in relapsed/refractory acute myeloid leukemia (AML) and multiple myeloma (MM) Blood. (2018) 132(Supplement 1):5790. doi: 10.1182/blood-2018-99-117974

101. Kawano Y, Fujiwara S, Wada N, Izaki M, Yuki H, Okuno Y, et al. Multiple myeloma cells expressing low levels of CD138 have an immature phenotype and reduced sensitivity to lenalidomide. Int J Oncol. (2012) 41:876-84. doi: 10.3892/ijo.2012.1545

102. Tian C, Yang H, Zhu L, Zhang Q, Cao Z, Zhang Y. Anti-CD138 chimeric antigen receptor-modified $\mathrm{T}$ cell therapy for multiple myeloma with extensive extramedullary involvement. Ann. Hematol. (2017) 96:140710. doi: 10.1007/s00277-017-3029-3

103. Ramani VC, Sanderson RD. Chemotherapy stimulates syndecan1 shedding: a potentially negative effect of treatment that may promote tumor relapse. Matrix Biol J Int Soc Matrix Biol. (2014) 35:215-22. doi: 10.1016/j.matbio.2013.10.005

104. Barber A, Meehan KR, Sentman CL. Treatment of multiple myeloma with adoptively transferred chimeric NKG2D receptor-expressing T Cells. Gene Ther. (2011) 18:509-16. doi: 10.1038/gt.2010.174

105. Baumeister SH, Murad J, Werner L, Daley H, Trebeden-Negre H, Gicobi JK, et al. Phase I trial of autologous CAR T cells targeting NKG2D ligands in patients with AML/MDS and multiple myeloma. Cancer Immunol Res. (2019) 7:100-12. doi: 10.1158/2326-6066.CIR-18-0307

106. Matsui W, Huff CA, Wang Q, Malehorn MT, Barber J, Tanhehco Y, et al. Characterization of clonogenic multiple myeloma cells. Blood. (2004) 103:2332-6. doi: 10.1182/blood-2003-09-3064

107. Hutchinson AT, Jones DR, Raison RL. Preclinical and clinical development of an anti-kappa free light chain mAb for multiple myeloma. Mol Immunol. (2015) 67:89-94. doi: 10.1016/j.molimm.2015.04.013

108. Mateos MV, Dimopoulos MA, Cavo M, Suzuki K, Jakubowiak A, Knop S, et al. Daratumumab plus bortezomib, melphalan, and prednisone for untreated myeloma. $N$ Engl J Med. (2018) 378:518-28. doi: 10.1056/NEJMoa1714678

109. Facon T, Kumar S, Plesner T, Orlowski RZ, Moreau P, Bahlis N, et al. Daratumumab plus lenalidomide and dexamethasone for untreated myeloma. N Engl J Med. (2019) 380:2104-15. doi: 10.1056/NEJMoa1817249

110. Dimopoulos MA, Oriol A, Nahi H, San-Miguel J, Bahlis NJ, Usmani SZ, et al. Daratumumab, lenalidomide, and dexamethasone for multiple myeloma. $N$ Engl J Med. (2016) 375:1319-31. doi: 10.1056/NEJMoa1607751

111. Palumbo A, Chanan-Khan A, Weisel K, Nooka AK, Masszi T, Beksac M, et al. Daratumumab, bortezomib, and dexamethasone for multiple myeloma. $N$ Engl J Med. (2016) 375:754-66. doi: 10.1056/NEJMoa1606038

112. Chari A, Suvannasankha A, Fay JW, Arnulf B, Kaufman JL, Ifthikharuddin JJ, et al. Daratumumab plus pomalidomide and dexamethasone in relapsed and/or refractory multiple myeloma. Blood. (2017) 130:97481. doi: 10.1182/blood-2017-05-785246

113. de Weers M, Tai YT, van der Veer MS, Bakker JM, Vink T, Jacobs DC, et al. Daratumumab, a novel therapeutic human CD38 monoclonal antibody, induces killing of multiple myeloma and other hematological tumors. $J$ Immunol Baltim Md. (2011) 186:1840-8. doi: 10.4049/jimmunol.1003032

114. Drent E, Themeli M, Poels R, de Jong-Korlaar R, Yuan H, de Bruijn J, et al. A rational strategy for reducing on-target off-tumor effects of CD38-chimeric antigen receptors by affinity optimization. Mol Ther J Am Soc Gene Ther. (2017) 25:1946-58. doi: 10.1016/j.ymthe.2017.04.024

115. Drent E, Groen RWJ, Noort WA, Themeli M, Lammerts van Bueren JJ, Parren PWHI, et al. Pre-clinical evaluation of CD38 chimeric antigen receptor engineered $\mathrm{t}$ cells for the treatment of multiple myeloma. Haematologica. (2016) 101:616-25. doi: 10.3324/haematol.2015.137620

116. Drent E, Poels R, Mulders MJ, van de Donk NWCJ, Themeli M, Lokhorst HM, et al. Feasibility of controlling CD38-CAR T cell activity with a Tet-on inducible CAR design. PLoS ONE. (2018) 13:e0197349. doi: 10.1371/journal.pone.0197349

117. Ding BB, Gray JD, Zhang N, Zhang Y, Cao X, Krapf I, et al. Development of an allogeneic anti-Bcma $\mathrm{T}$ cell therapy utilizing a novel dimeric antigen receptor (DAR) structure. Blood. (2019) 134(Suppl_ 1):1942. doi: 10.1182/blood-2019-131892 
118. Atamaniuk J, Gleiss A, Porpaczy E, Kainz B, Grunt TW, Raderer M, et al. Overexpression of $\mathrm{G}$ Protein-coupled receptor 5D in the bone marrow is associated with poor prognosis in patients with multiple myeloma. Eur J Clin Invest. (2012) 42:953-60. doi: 10.1111/j.1365-2362.2012.02679.x

119. Cohen Y, Gutwein O, Garach-Jehoshua O, Bar-Haim A, Kornberg A. GPRC5D is a promising marker for monitoring the tumor load and to target multiple myeloma cells. Hematol Amst Neth. (2013) 18:34851. doi: 10.1179/1607845413Y.0000000079

120. Smith EL, Harrington K, Staehr M, Masakayan R, Jones J, Long TJ, et al. GPRC5D is a target for the immunotherapy of multiple myeloma with rationally designed CAR T cells. Sci Transl Med. (2019) 11:eaau7746. doi: 10.1126/scitranslmed.aau7746

121. Fernandez de Larrea C, Staehr M, Lopez A, Chen Y, Purdon TJ, Ng KY, et al. Optimal dual-targeted CAR construct simultaneously targeting $\mathrm{Bcma}$ and GPRC5D prevents Bcma-escape driven relapse in multiple myeloma. Blood. (2019) 134(Suppl_1):136. doi: 10.1182/blood-2019-126145

122. Van Camp B, Durie BG, Spier C, De Waele M, Van Riet I, Vela E, et al. Plasma cells in multiple myeloma express a natural killer cell-associated antigen: CD56 (NKH-1; Leu-19) Blood. (1990) 76:377-82.

123. Ailawadhi S, Kelly KR, Vescio RA, Jagannath S, Wolf J, Gharibo M, et al. A phase I study to assess the safety and pharmacokinetics of single-agent lorvotuzumab mertansine (IMGN901) in patients with relapsed and/or refractory CD-56-positive multiple myeloma. Clin. Lymphoma Myeloma Leuk. (2019) 19:29-34. doi: 10.1016/j.clml.2018.08.018

124. Jiang C, Zhao W, Qin M, Jin M, Chang L, Ma X. CD56chimeric antigen receptor T-cell therapy for refractory/recurrent rhabdomyosarcoma: a 3.5-year follow-up case report. Medicine. (2019) 98:e17572. doi: 10.1097/MD.0000000000017572

125. Benjamin R, Condomines M, Gunset G, Sadelain M. CD56 targeted chimeric antigen receptors for immunotherapy of multiple myeloma. Cancer Res. (2012) 72 (8 Suppl.):3499. doi: 10.1158/1538-7445.AM2012-3499

126. Gnjatic S, Nishikawa H, Jungbluth AA, Güre AO, Ritter G, Jäger E, et al. NYESO-1: review of an immunogenic tumor antigen. Adv Cancer Res. (2006) 95:1-30. doi: 10.1016/S0065-230X (06) 95001-5

127. Dhodapkar MV, Osman K, Teruya-Feldstein J, Filippa D, Hedvat CV, Iversen $\mathrm{K}$, et al. Expression of cancer/testis (CT) antigens MAGE-A1, MAGE-A3, MAGE-A4, CT-7, and NY-ESO-1 in malignant gammopathies is heterogeneous and correlates with site, stage and risk status of disease. Cancer Immun. (2003) 3:9.

128. van Rhee F, Szmania SM, Zhan F, Gupta SK, Pomtree M, Lin P, et al. NY-ESO-1 is highly expressed in poor-prognosis multiple myeloma and induces spontaneous humoral and cellular immune responses. Blood. (2005) 105:3939-44. doi: 10.1182/blood-2004-09-3707

129. Rapoport AP, Stadtmauer EA, Binder-Scholl GK, Goloubeva O, Vogl DT, Lacey SF, et al. NY-ESO-1-specific TCR-engineered T cells mediate sustained antigen-specific antitumor effects in myeloma. Nat. Med. (2015) 21:91421. doi: $10.1038 / \mathrm{nm} .3910$

130. Stadtmauer EA, Faitg TH, Lowther DE, Badros AZ, Chagin K, Dengel $\mathrm{KM}$, et al. Long-term safety and activity of NY-ESO-1 SPEAR T cells after autologous stem cell transplant for myeloma. Blood Adv. (2019) 3:202234. doi: 10.1182/bloodadvances.2019000194

131. Mastaglio S, Genovese P, Magnani Z, Ruggiero E, Landoni E, Camisa B, et al. NY-ESO-1 TCR single edited stem and central memory $\mathrm{t}$ cells to treat multiple myeloma without graft-versushost disease. Blood. (2017) 130:606-18. doi: 10.1182/blood-2016-08732636

132. Li C, Mei H, Hu Y, Guo T, Liu L, Jiang H, et al. A bispecific CAR$\mathrm{T}$ cell therapy targeting $\mathrm{Bcma}$ and $\mathrm{CD} 38$ for relapsed/refractory multiple myeloma: updated results from a phase 1 dose-climbing trial. Blood. (2019) 134(Suppl_1):930. doi: 10.1182/blood-2019-130340

133. Popat R, Zweegman S, Cavet J, Yong K, Lee L, Faulkner J, et al. Phase 1 first-in-human study of AUTO2, the first chimeric antigen receptor (CAR) T cell targeting APRIL for patients with relapsed/refractory multiple myeloma (RRMM) Blood. (2019) 134(Suppl_1):3112. doi: 10.1182/blood-2019-126689

134. Hosen N, Matsunaga Y, Hasegawa K, Matsuno H, Nakamura Y, Makita $\mathrm{M}$, et al. The activated conformation of integrin B7 is a novel multiple myeloma-specific target for CAR T cell therapy. Nat. Med. (2017) 23:143643. doi: $10.1038 / \mathrm{nm} .4431$
135. Yousef S, Kovacsovics-Bankowski M, Salama ME, Bhardwaj N, Steinbach M, Langemo A, et al. CD229 is expressed on the surface of plasma cells carrying an aberrant phenotype and chemotherapy-resistant precursor cells in multiple myeloma. Hum Vaccines Immunother. (2015) 11:160611. doi: 10.1080/21645515.2015.1046658

136. Venniyil Radhakrishnan S, Luetkens T, Yousef S, Bhardwaj N, Steinbach $\mathrm{MN}$, Weidner J, et al. Chimeric antigen receptor (CAR) $\mathrm{T}$ cells specific for CD229: a potentially curative approach for multiple myeloma. Blood. (2017) 130(Suppl. 1):3142. doi: 10.1182/blood.V130.Suppl/1.3142.3142

137. Radhakrishnan SV, Luetkens T, Scherer SD, Davis P, Vander Mause ER, Olson ML, et al. CD229 CAR T cells eliminate multiple myeloma and tumor propagating cells without fratricide. Nat Commun. (2020) 11:798. doi: 10.1038/s41467-020-14619-z

138. Gagelmann N, Ayuk FA, Atanackovic D, Kroeger N. B cell maturation antigen-specific CAR $\mathrm{T}$ cells for relapsed or refractory multiple myeloma: a meta-analysis. Blood. (2019) 134(Supplement 1):3113. doi: 10.1182/blood-2019-121967

139. Jensen MC, Popplewell L, Cooper LJ, Di Giusto D, Kalos M, Ostberg JR, et al. Antitransgene rejection responses contribute to attenuated persistence of adoptively transferred cd20/cd19-specific chimeric antigen receptor redirected T cells in humans. Biol Blood Marrow Transpl. (2010) 16:124556. doi: 10.1016/j.bbmt.2010.03.014

140. Gorovits B, Koren E. Immunogenicity of chimeric antigen receptor Tcell therapeutics. Bio Drugs Clin Immunother Biopharm Gene Ther. (2019) 33:275-84. doi: 10.1007/s40259-019-00354-5

141. Ajina A, Maher J. Strategies to address chimeric antigen receptor tonic signaling. Mol. Cancer Ther. (2018) 17:179515. doi: 10.1158/1535-7163.MCT-17-1097

142. Long AH, Haso WM, Shern JF, Wanhainen KM, Murgai M, Ingaramo $\mathrm{M}$, et al. 4-1BB costimulation ameliorates $\mathrm{T}$ cell exhaustion induced by tonic signaling of chimeric antigen receptors. Nat. Med. (2015) 21:58190. doi: $10.1038 / \mathrm{nm} .3838$

143. Milone MC, Fish JD, Carpenito C, Carroll RG, Binder GK, Teachey D, et al. Chimeric receptors containing CD137 signal transduction domains mediate enhanced survival of T cells and increased antileukemic efficacy in vivo. Mol Ther J Am Soc Gene Ther. (2009) 17:1453-64. doi: 10.1038/mt.2009.83

144. Gomes-Silva D, Mukherjee M, Srinivasan M, Krenciute G, Dakhova O, Zheng $\mathrm{Y}$, et al. Tonic 4-1BB costimulation in chimeric antigen receptors impedes T cell survival and is vector-dependent. Cell Rep. (2017) 21:1726. doi: 10.1016/j.celrep.2017.09.015

145. Hermanson DL, Barnett BE, Rengarajan S, Codde R, Wang $\mathrm{X}$, Tan Y, et al. A novel Bcma-specific, centyrin-based CAR-T product for the treatment of multiple myeloma. Blood. (2016) 128:2127. doi: 10.1182/blood.V128.22.2127.2127

146. Watanabe N, Bajgain P, Sukumaran S, Ansari S, Heslop HE, Rooney $\mathrm{CM}$, et al. Fine-tuning the CAR spacer improves T-cell potency. Oncoimmunology. (2016) 5:e1253656. doi: 10.1080/2162402X.2016.1253656

147. Hudecek M, Sommermeyer D, Kosasih PL, Silva-Benedict A, Liu L, Rader $\mathrm{C}$, et al. The nonsignaling extracellular spacer domain of chimeric antigen receptors is decisive for in vivo antitumor activity. Cancer Immunol Res. (2015) 3:125-35. doi: 10.1158/2326-6066.CIR-14-0127

148. Kuhn NF, Purdon TJ, van Leeuwen DG, Lopez AV, Curran KJ, Daniyan AF, et al. CD40 ligand-modified chimeric antigen receptor $t$ cells enhance antitumor function by eliciting an endogenous antitumor response. Cancer Cell. (2019) 35:473-88.e6. doi: 10.1016/j.ccell.2019. 02.006

149. Rafiq S, Yeku OO, Jackson HJ, Purdon TJ, van Leeuwen DG, Drakes DJ, et al. Targeted delivery of a PD-1-blocking Sc Fv by CAR-T cells enhances anti-tumor efficacy in vivo. Nat Biotechnol. (2018) 36:84756. doi: 10.1038/nbt.4195

150. Sommermeyer D, Hudecek M, Kosasih PL, Gogishvili T, Maloney DG, Turtle $\mathrm{CJ}$, et al. Chimeric antigen receptor-modified $\mathrm{T}$ cells derived from defined $\mathrm{CD} 8+$ and $\mathrm{CD} 4+$ subsets confer superior antitumor reactivity in vivo. Leukemia. (2016) 30:492-500. doi: 10.1038/leu.2015.247

151. Wang M, Pruteanu I, Cohen AD, Garfall AL, Milone MC, Tian L, et al. Identification and validation of predictive biomarkers to CD19- and BCMASpecific CAR T-cell responses in CAR T-cell precursors. Blood. (2019) 134(Suppl_1):622. doi: 10.1182/blood-2019-122513 
152. Zheng W, O’Hear CE, Alli R, Basham JH, Abdelsamed HA, Palmer LE, et al. PI3K orchestration of the in vivo persistence of chimeric antigen receptor-modified $t$ cells. Leukemia. (2018) 32:1157-67. doi: 10.1038/s41375-017-0008-6

153. Borrello I, Noonan KA. Marrow-infiltrating lymphocytes role in biology and cancer therapy. Front. Immunol. (2016) 7:112. doi: 10.3389/fimmu.2016.00112

154. Lutz ER, Jana S, Rudraraju L, De Oliveira E, Zhou J, Mackay S, et al. Superior efficacy of CAR-T cells using marrow-infiltrating lymphocytes (MILs TM) as compared to peripheral blood lymphocytes (PBLs) Blood. (2019) 134(Suppl_1):4437. doi: 10.1182/blood-2019-130629

155. Eyquem J, Mansilla-Soto J, Giavridis T, van der Stegen SJC, Hamieh $\mathrm{M}$, Cunanan $\mathrm{KM}$, et al. Targeting a CAR to the TRAC locus with CRISPR/Cas9 enhances tumour rejection. Nature. (2017) 543:113-7. doi: 10.1038/nature21405

156. Poirot L, Philip B, Schiffer-Mannioui C, Le Clerre D, Chion-Sotinel I, Derniame S, et al. Multiplex genome-edited T-cell manufacturing platform for "off-the-shelf" adoptive T-cell immunotherapies. Cancer Res. (2015) 75:3853-64. doi: 10.1158/0008-5472.CAN-14-3321

157. Depil S, Duchateau P, Grupp SA, Mufti G, Poirot, L. "Off-the-Shelf” allogeneic CAR T cells: development and challenges. Nat Rev Drug Discov. (2020) 19:185-99. doi: 10.1038/s41573-019-0051-2

158. Sommer C, Boldajipour B, Valton J, Galetto R, Bentley T, Sutton J, et al. ALLO-715, an allogeneic BCMA CAR T therapy possessing an off-switch for the treatment of multiple myeloma. Blood. (2018) 132(Supplement 1):591. doi: 10.1182/blood-2018-99-119227

159. Cranert SA, Richter M, Tong M, Weiss L, Tan Y, Ostertag EM, et al. Manufacture of an allogeneic CAR-T stem cell memory product candidate for multiple myeloma, P-Bcma-ALLO1, is robust, reproducible and highly scalable. Blood. (2019) 134(Suppl_1):4445. doi: 10.1182/blood-2019-131839

160. Maciocia P, Wawrzyniecka P, Kassimatis L, Pule M.A protein-based method to develop allogeneic chimeric antigen receptor T-cells. Blood. (2018) 132(Suppl_1):700. doi: 10.1182/blood-2018-99-112544

161. Antony PA, Piccirillo CA, Akpinarli A, Finkelstein SE, Speiss PJ, Surman $\mathrm{DR}$, et al. CD8+ $\mathrm{T}$ cell immunity against a tumor/self-antigen is augmented by $\mathrm{CD} 4+\mathrm{t}$ helper cells and hindered by naturally occurring t regulatory cells. J Immunol Baltim Md. (1950) (2005) 174:2591601. doi: 10.4049/jimmunol.174.5.2591

162. Gattinoni L, Finkelstein SE, Klebanoff CA, Antony PA, Palmer DC, Spiess PJ, et al. Removal of homeostatic cytokine sinks by lymphodepletion enhances the efficacy of adoptively transferred tumor-specific CD8+ T cells. J Exp Med. (2005) 202:907-12. doi: 10.1084/jem.20050732

163. Hirayama AV, Gauthier J, Hay KA, Voutsinas JM, Wu Q, Gooley T, et al. The response to lymphodepletion impacts PFS in patients with aggressive non-hodgkin lymphoma treated with CD19 CAR T cells. Blood. (2019) 133:1876-87. doi: 10.1182/blood-2018-11-887067

164. Neelapu SS. CAR-T efficacy: is conditioning the key? Blood. (2019) 133:1799800. doi: 10.1182/blood-2019-03-900928

165. Suen H, Brown R, Yang S, Weatherburn C, Ho PJ, Woodland N, et al. Multiple myeloma causes clonal T-cell immunosenescence: identification of potential novel targets for promoting tumour immunity and implications for checkpoint blockade. Leukemia. (2016) 30:1716-24. doi: 10.1038/leu.2016.84

166. Danhof S, Schreder M, Knop S, Rasche L, Strifler S, Löffler C, et al. Expression of programmed death-1 on lymphocytes in myeloma patients is lowered during lenalidomide maintenance. Haematologica. (2018) 103:e1269. doi: 10.3324/haematol.2017.178947

167. Garfall AL, Dancy EK, Cohen AD, Hwang, W-T Fraietta JA, Davis MM, et al. T-cell phenotypes associated with effective CAR T-cell therapy in postinduction vs relapsed multiple myeloma. Blood Adv. (2019) 3:28125. doi: 10.1182/bloodadvances. 2019000600

168. Alexanian R, Salmon S, Bonnet J, Gehan E, Haut A, Weick J. Combination therapy for multiple myeloma. Cancer. (1977) 40:2765-71. doi: 10.1002/1097-0142(197712) 40:6<2765::aid-cncr2820400602>3.0.co;2-X

169. Wang X, Walter M, Urak R, Weng L, Huynh C, Lim L, et al. Lenalidomide enhances the function of CS1 chimeric antigen receptorredirected T cells against multiple myeloma. Clin Cancer Res. (2018) 24:10619. doi: 10.1158/1078-0432.CCR-17-0344
170. Works M, Soni N, Hauskins C, Sierra C, Baturevych A, Jones JC, et al. Anti$\mathrm{B}$-cell maturation antigen chimeric antigen receptor $\mathrm{T}$ cell function against multiple myeloma is enhanced in the presence of lenalidomide. Mol. Cancer Ther. (2019) 18:2246-57. doi: 10.1158/1535-7163.MCT-18-1146

171. Bernabei L, Garfall AL, Melenhorst JJ, Lacey SF, Stadtmauer EA, Vogl DT, et al. PD-1 inhibitor combinations as salvage therapy for relapsed/refractory multiple myeloma (MM) patients progressing after Bcma-directed CAR T cells. Blood. (2018) 132(Supplement 1):1973. doi: 10.1182/blood-2018-99-119514

172. Smith EL, Mailankody S, Staehr M, Wang X, Senechal B, Purdon TJ, et al. BCMA-targeted CAR T-cell therapy plus radiotherapy for the treatment of refractory myeloma reveals potential synergy. Cancer Immunol Res. (2019) 7:1047-53. doi: 10.1158/2326-6066.CIR-18-0551

173. Majzner RG, Mackall CL. Tumor antigen escape from CAR T-cell therapy. Cancer Discov. (2018) 8:1219-26. doi: 10.1158/2159-8290.CD-18-0442

174. Balakrishnan A, Rajan A, Salter AI, Kosasih PL, Wu Q, Voutsinas $\mathrm{J}$, et al. Multispecific targeting with synthetic ankyrin repeat motif chimeric antigen receptors. Clin Cancer Res. (2019) 25:7506-16. doi: 10.1158/1078-0432.CCR-19-1479

175. Lee L, Draper B, Chaplin N, Philip B, Chin M, Galas-Filipowicz D, et al. An APRIL-based chimeric antigen receptor for dual targeting of BCMA and TACI in multiple myeloma. Blood. (2018) 131:74658. doi: 10.1182/blood-2017-05-781351

176. Chen KH, Wada M, Pinz KG, Liu H, Shuai X, Chen X, et al. A compound chimeric antigen receptor strategy for targeting multiple myeloma. Leukemia. (2018) 32:402-12. doi: 10.1038/leu.2017.302

177. Zah E, Nam E, Bhuvan V, Tran U, Ji BY, Gosliner SB, et al. Systematically optimized BCMA/CS1 Bispecific CAR-T cells robustly control heterogeneous multiple myeloma. Nat Commun. (2020) 11:2283. doi: 10.1038/s41467-020-16160-5

178. Zhang H, Gao L, Liu L, Wang J, Wang S, Gao L, et al. Bcma $\mathrm{X}$, and CD19 Bispecific CAR-T for relapsed and refractory multiple myeloma. Blood. (2019) 134(Suppl_1):3147. doi: 10.1182/blood-2019131056

179. Nijhof IS, Groen RWJ, Lokhorst HM, van Kessel B, Bloem AC, van Velzen J, et al. Upregulation of CD38 expression on multiple myeloma cells by alltrans retinoic acid improves the efficacy of daratumumab. Leukemia. (2015) 29:2039. doi: 10.1038/leu.2015.123

180. García-Guerrero E, Gogishvili T, Danhof S, Schreder M, Pallaud C, Pérez-Simón JA, et al. Panobinostat induces CD38 upregulation and augments the antimyeloma efficacy of daratumumab. Blood. (2017) 129:3386. doi: 10.1182/blood-2017-03-770776

181. García-Guerrero E, Götz R, Doose S, Sauer M, Rodríguez-Gil A, Nerreter $\mathrm{T}$, et al. Upregulation of CD38 expression on multiple myeloma cells by novel HDAC6 inhibitors is a class effect and augments the efficacy of daratumumab. Leukemia. (2020). doi: 10.1038/s41375-020-0840-y. [Epub ahead of print].

182. Pont MJ, Hill T, Cole GO, Abbott JJ, Kelliher J, Salter AI, et al. $\gamma$ secretase inhibition increases efficacy of BCMA-specific chimeric antigen receptor $\mathrm{T}$ cells in multiple myeloma. Blood. (2019) 134:1585-97. doi: 10.1182/blood.2019000050

183. Cowan AJ, Pont M, Sather BD, Turtle CJ, Till BG, Nagengast AM, et al. Efficacy and safety of fully human Bcma CAR $\mathrm{T}$ cells in combination with a gamma secretase inhibitor to increase bcma surface expression in patients with relapsed or refractory multiple myeloma. Blood. (2019) 134(Suppl_1):204.doi: 10.1182/blood-2019-129405

184. Bonifant CL, Jackson HJ, Brentjens RJ, Curran KJ. Toxicity and management in CAR T-cell therapy. Mol Ther Oncol. (2016) 3:16011. doi: $10.1038 / \mathrm{mto} .2016 .11$

185. Neelapu SS, Tummala S, Kebriaei P, Wierda W, Gutierrez C, Locke FL, et al. Chimeric antigen receptor T-cell therapy - assessment and management of toxicities. Nat Rev Clin Oncol. (2018) 15:4762. doi: $10.1038 /$ nrclinonc. 2017.148

186. Lee DW, Santomasso BD, Locke FL, Ghobadi A, Turtle CJ, Brudno JN, et al. ASTCT consensus grading for cytokine release syndrome and neurologic toxicity associated with immune effector cells. Biol Blood Marrow Transpl. (2019) 25:625-38. doi: 10.1016/j.bbmt.2018.12.758 
187. Yáñez L, Sánchez-Escamilla M, Perales M-A. CAR T cell toxicity: current management and future directions. Hema Sphere. (2019) 3:e186. doi: 10.1097/HS9.0000000000000186

188. Neelapu SS. Managing the toxicities of CAR T-Cell therapy. Hematol Oncol. (2019) 37(Suppl. 1):48-52. doi: 10.1002/hon.2595

189. Yakoub-Agha I, Chabannon C, Bader P, Basak GW, Bonig H, Ciceri F, et al. Management of adults and children undergoing chimeric antigen receptor $\mathrm{t}$-cell therapy: best practice recommendations of the European Society for Blood and Marrow Transplantation (EBMT) and the joint accreditation committee of ISCT and EBMT (JACIE) Haematologica. (2020) 105:297316. doi: 10.3324/haematol.2019.229781

190. Shimabukuro-Vornhagen A, Gödel P, Subklewe M, Stemmler HJ, Schlößer HA, Schlaak M, et al. Cytokine release syndrome. I Immunother Cancer. (2018) 6:56. doi: 10.1186/s40425-018-0343-9

191. Mosser DM, Edwards JP. Exploring the full spectrum of macrophage activation. Nat Rev Immunol. (2008) 8:958-69. doi: 10.1038/nri2448

192. Hay KA, Hanafi LA, Li D, Gust J, Liles WC, Wurfel MM, et al. Kinetics and biomarkers of severe cytokine release syndrome after CD19 chimeric antigen receptor-modified T-cell therapy. Blood. (2017) 130:2295306. doi: 10.1182/blood-2017-06-793141

193. Giavridis T, van der Stegen SJC, Eyquem J, Hamieh M, Piersigilli A, Sadelain, et al. CAR T cell-induced cytokine release syndrome is mediated by macrophages and abated by IL-1 Blockade. Nat Med. (2018) 24:7318. doi: 10.1038/s41591-018-0041-7

194. Lee DW, Gardner R, Porter DL, Louis CU, Ahmed N, Jensen M, et al. Current concepts in the diagnosis and management of cytokine release syndrome. Blood. (2014) 124:188-95. doi: 10.1182/blood-2014-05-552729

195. Mahadeo KM, Khazal SJ, Abdel-Azim H, Fitzgerald JC, Taraseviciute A, Bollard CM, et al. Management guidelines for paediatric patients receiving chimeric antigen receptor T cell therapy. Nat Rev Clin Oncol. (2019) 16:4563. doi: 10.1038/s41571-018-0075-2

196. Brudno JN, Kochenderfer JN. Toxicities of chimeric antigen receptor $\mathrm{T}$ cells: recognition and management. Blood. (2016) 127:3321-30. doi: 10.1182/blood-2016-04-703751

197. Le RQ, Li L, Yuan W, Shord SS, Nie L, Habtemariam BA, et al. FDA approval summary: tocilizumab for treatment of chimeric antigen receptor $\mathrm{T}$ cellinduced severe or life-threatening cytokine release syndrome. Oncologist. (2018) 23:943-7. doi: 10.1634/theoncologist.2018-0028

198. Mestermann K, Giavridis T, Weber J, Rydzek J, Frenz S, Nerreter $\mathrm{T}$, et al. The tyrosine kinase inhibitor dasatinib acts as a pharmacologic on/off switch for CAR T cells. Sci Transl Med. (2019) 11:499. doi: 10.1126/scitranslmed.aau5907

199. Gust J, Hay KA, Hanafi LA, Li D, Myerson D, Gonzalez-Cuyar LF, et al. Endothelial activation and blood-brain barrier disruption in neurotoxicity after adoptive immunotherapy with CD19 CAR-T cells. Cancer Discov. (2017) 7:1404-19. doi: 10.1158/2159-8290.CD-17-0698

200. Santomasso BD, Park JH, Salloum D, Riviere I, Flynn J, Mead E, et al. Clinical and biological correlates of neurotoxicity associated with CAR T-cell therapy in patients with B-cell acute lymphoblastic leukemia. Cancer Discov. (2018) 8:958-71. doi: 10.1158/2159-8290.CD-17-1319

201. Taraseviciute A, Tkachev V, Ponce R, Turtle CJ, Snyder JM, Liggitt $\mathrm{HD}$, et al. Chimeric antigen receptor $\mathrm{T}$ cell-mediated neurotoxicity in nonhuman primates. Cancer Discov. (2018) 8:750-63. doi: 10.1158/2159-8290.CD-17-1368

202. Teachey DT, Bishop MR, Maloney DG, Grupp SA. Toxicity management after chimeric antigen receptor T Cell therapy: one size does not fit "ALL." Nat Rev Clin Oncol. (2018) 15:218. doi: 10.1038/nrclinonc.2018.19
203. Lamers CH, Sleijfer S, van Steenbergen S, van Elzakker P, van Krimpen B, Groot C, et al. Treatment of metastatic renal cell carcinoma with CAIX CARengineered T cells: clinical evaluation and management of on-target toxicity. Mol Ther J Am Soc Gene Ther. (2013) 21:904-12. doi: 10.1038/mt.2013.17

204. Morgan RA, Yang JC, Kitano M, Dudley ME, Laurencot CM, Rosenberg SA. Case report of a serious adverse event following the administration of T cells transduced with a chimeric antigen receptor recognizing ERBB2. Mol Ther J Am Soc Gene Ther. (2010) 18:843-51. doi: 10.1038/mt.2010.24

205. Hacein-Bey-Abina S, Garrigue A, Wang GP, Soulier J, Lim A, Morillon E, et al. Insertional oncogenesis in 4 patients after retrovirus-mediated gene therapy of SCID-X1. J Clin Invest. (2008) 118:3132-42. doi: 10.1172/JCI35700

206. Scholler J, Brady TL, Binder-Scholl G, Hwang WT, Plesa G, Hege KM, et al. Decade-long safety and function of retroviralmodified chimeric antigen receptor T cells. Sci Transl Med. (2012) 4:132ra53. doi: 10.1126/scitranslmed.3003761

207. Fraietta JA, Nobles CL, Sammons MA, Lundh S, Carty SA, Reich TJ, et al. Disruption of TET2 promotes the therapeutic efficacy of CD19-targeted T cells. Nature. (2018) 558:307-312. doi: 10.1038/s41586-018-0178-z

208. Gagelmann N, Ayuk F, Atanackovic D, Kröger N. B cell maturation antigen-specific chimeric antigen receptor $\mathrm{T}$ cells for relapsed or refractory multiple myeloma: a meta-analysis. Eur J Haematol. (2020) 104:318-27. doi: 10.1111/ejh.13380

209. Raedler LA. Revlimid (lenalidomide) now FDA approved as first-line therapy for patients with multiple myeloma. Am Health Drug Benefits. (2016) 9:140-3.

210. Moreau P, Attal M, Hulin C, Arnulf B, Belhadj K, Benboubker L-S, et al. Bortezomib, thalidomide, and dexamethasone with or without daratumumab before and after autologous stem-cell transplantation for newly diagnosed multiple myeloma (CASSIOPEIA): A randomised, open-label, phase 3 study. Lancet. (2019) 394:29-38. doi: 10.1016/S0140-6736(19) 31240-1

211. Wester $\mathrm{R}$, van der Holt B, Asselbergs E, Zweegman S, Kersten MJ, Vellenga E, et al. Phase II study of carfilzomib, thalidomide, and low-dose dexamethasone as induction and consolidation in newly diagnosed, transplant eligible patients with multiple myeloma; the carthadex trial. Haematologica. (2019) 104:2265-73. doi: 10.3324/haematol.2018. 205476

212. ICER (Institute for Clinical and Economic Review) and CTAF (California Technology Assessment Forum). Chimeric Antigen Receptor T-Cell Therapy for B-Cell Cancers: Effectiveness and Value. Final Evidence Report (2018).

213. Lin JK, Lerman BJ, Barnes JI, Boursiquot BC, Tan YJ, Robinson AQL, et al. Cost effectiveness of chimeric antigen receptor t-cell therapy in relapsed or refractory pediatric B-cell acute lymphoblastic leukemia. J Clin Oncol. (2018) 36:3192-202. doi: 10.1200/JCO.2018.79.0642

Conflict of Interest: The authors declare that the research was conducted in the absence of any commercial or financial relationships that could be construed as a potential conflict of interest.

Copyright (c) 2020 Rodríguez-Lobato, Ganzetti, Fernández de Larrea, Hudecek, Einsele and Danhof. This is an open-access article distributed under the terms of the Creative Commons Attribution License (CC BY). The use, distribution or reproduction in other forums is permitted, provided the original author(s) and the copyright owner(s) are credited and that the original publication in this journal is cited, in accordance with accepted academic practice. No use, distribution or reproduction is permitted which does not comply with these terms. 